\title{
Evolução Pedomorfológica das Vertentes em Conceição do Araguaia(PA): Abordagem Metodológica e Evidências Macro e Micromorfológicas (1)
}

\author{
Hillslope Pedomorphological Evolution in Conceição do Araguaia (PA): \\ Methodological Approach and Macro and Micromorphological Evidences (1)
}

\author{
Nádia Regina do Nascimento (2) e Diosvany Hernandez Perez (2)
}

(1) Pesquisa financiada pela FAPESP (2) DEPLAN/IGCE UNESP. Rua 10 no. 2527. 13500-230, Rio Claro,

(2) SP. Tel.(19) 5262241, Fax: (19) 5348250, email: nascimr@ms.rc.unesp.br.

\begin{abstract}
RESUMO
Processos erosivos mecânicos, sucessivos no tempo e no espaço, são, prioritariamente, considerados pelos geomorfólogos como responsáveis pela morfogênese. Estudos de sistemas de solos em toposseqüências a propósito da mineralogia e estrutura de solos e alteritas foram fundamentais para mostrar a importância da alteração e da pedogênese como agentes morfogenéticos. Sistemas de solos são entendidos como unidades funcionais e de processos e podem constituir o parâmetro de delimitação de unidades geoambientais. $\mathrm{O}$ estudo da pedomorfologia do relevo, apresentado neste artigo, partiu da hipótese de que a distribuição espacial e a evolução das unidades pedo-geomorfológicas acompanham a evolução dos sistemas de solos e não são, necessariamente, o resultado de processos erosivos mecânicos. Este trabalho combina procedimentos de campo com análises de laboratório (microscopia óptica, análises texturais, químicas, mineralógicas e análises por microscopia eletrônica por varredura e por transmissão). A área de estudo está localizada no sul da Amazônia Brasileira, sob clima tropical úmido, em uma zona de transição floresta/cerrado. Os resultados obtidos mostram que a evolução dos sistemas de solos tem caráter determinante na evolução pedogeomorfológica: um longo processo de laterização com encouraçamento ferruginoso e latossolização foi o responsável pelo aplainamento e abaixamento dos relevos; o Latossolo transforma a couraça e provoca uma leve convexização das encostas dos platôs; a expansão de um Argissolo provoca uma mudança fundamental na forma dos relevos fazendo aparecer lombadas convexas.
\end{abstract}

Palavras Chave: pedomorfologia de relevos, sistemas de solos, laterização.

\begin{abstract}
Mechanical erosive processes, successively occurring in time and space, are, majorily, accounted by geomorphologists as responsible for morphogenesis. Soil systems studies through toposequences, regarding aspects of soils and alterite mineralogy and structure have been crucial in order to show the importance of alteration and pedogenesis as morphogenetical agents. Soil systems are understood as functional and process unities and may represent the parameter for delimiting geo-environmental unities. The study of pedomorphology of landforms, us put forward in this article, is based on the hypothesis that the spatial distribution and evolution of pedo-geomorphological unities follow the evolution of soil systems and, therefore, are not, necesseraly the result of mechanical erosive processes. The present study combines field investigation procedures with laboratory analysis (optical microscopy, textural analysis, chemical, mineralogical and SEM analysis). The study-area is situated in the south of Brasilian Amazon, under a humid tropical climate in the forest/savannah transition zone. The results show that the evolution of soil systems play a determinant role in the geomorphological evolution of the areas: a long-lasting laterisation process followed by the formation of a ferruginous duricrust and latossolization accounts for the leveling and lowering of landforms; the lateritic soil transforms the ferruginous duricrust and convert the slope of the plateaux to a smooth convex shape; the expassion of a clay-rich soil (argissol) causes a fundamental change in the shape of landforms generating convex "noses".
\end{abstract}

Keywords: landforms pedomorphology, soil systems, laterisation. 


\section{Introdução}

A NE de Conceição do Araguaia ocorrem três níveis topográficos decrescentes (I, II e III), organizados a partir do centro da área para leste, na direção do Rio Araguaia, e para oeste, na direção do Rio Arraias (Fig 1). A transição entre os níveis é, algumas vezes, gradual ou, mais geralmente, nítida e marcada por uma leve dissecação. As superfícies são revestidas por duas coberturas: encouraçada ferruginosa laterítica e latossólica com restos de couraça ferruginosa ou por um argissolo (lixiviado/pedregoso com B argiloso/hidromórfico e restos de couraça ferruginosa). Um sistema de solos latossolo/argissolo caracteriza as transições entre as superfícies II e III.

Boaventura (1974) considera essa área como resultante da atuação de processos de pediplanação pleistocênica e de processos erosivos fluviais póspliocênicos. Entretanto, o sistema de solo Couraça ferruginosa laterítica/Latossolo foi reconhecido por Nahon, Melfi e Conte (1989), em área próxima ao município de Conceição do Araguaia, como um sistema de transformação pedológica.

O reconhecimento do intemperismo tropical como agente morfogenético é fato recente e a interpretação dos processos e dos produtos do intemperismo nos diferentes sistemas geomorfológicos ainda não foi exaustivamente estudada (Thomas, 1994), embora pedólogos e geomorfólogos, em trabalhos realizados na África, sobretudo na década de 1970, bem como no Brasil, nas décadas de 1980 e 1990, tenham trazido importantes contribuições para o entendimento dos principais processos responsáveis pela evolução dos relevos (McFarlane, 1976; Millot, 1977, 1979; Bocquier et al., 1977; Boulet et al., 1977; Nahon e Millot, 1977; Löffler, 1978; Busche e Erb, 1987; MacFarlane e Twidale, 1987; Fritsch et al., 1990, Lucas et al. 1984; Lucas 1989; Castro 1989; Nascimento 1993, Filizola 1993; Boulet et al. 1993; Nascimento e Carvalho 1996 e Perez, Nascimento e Nicola 1998, dentre outros).

Estudos dos sistemas de solos através de toposseqüências (seções pedológicas transversais aos eixos de maior declive), com ênfase nas suas estruturas e respectivas constituições mineralógicas, mostraram que as formações supérgenas constituemse num contínuo, dentro do qual pode-se diferenciar vertical e lateralmente grandes compartimentos ou unidades pedo-estruturais que constituem e configuram sistemas de solos. Estes são visíveis na escala as vertentes e distribuem-se superpostos ou embutidos, um nos outros geralmente de modo concordante com as formas do modelado do relevo das paisagens, condicioná-los aos grandes eixos de drenagem das bacias hidrográficas, constituindo-se em unidades pedo-geomorfológicas, (Boulet, 1978; Nahon, 1976, Fritsch, 1984; Lucas, 1989; Fritsch, Peterschmitt e Herbillon, 1992)

Essas distribuições nas paisagens permitem estabelecer as cronologias relativas de formação desses sistemas de solos, dos respectivos constituintes e sua interpretação como unidades funcionais (Peterschimitt, Fritsch, Rajot e Herbillon, 1996; Fritsch et al, 1999). Associados às formas do relevo e entendidos como unidades funcionais e processuais podem constituir-se também em parâmetro para a delimitação de unidades geoambientais.

Este estudo apresenta uma interpretação sobre a evolução pedo-morfológica da área de Conceição do Araguaia, desenvolvida com base na aplicação de uma abordagem metodológica que articula escalas sucessivas de aproximação, isto é das paisagens ao microscópio (Boulet et al, 1982 a, b, c) e vice versa, com o objetivo de compreender as relações genéticas entre os sistemas de solos e o modelado do relevo presentes na área, com ênfase na zona de transição climática entre a Amazônia e o Cerrado no Brasil, destacando-se as evidencias macro e micromorfológicas dos solos.

\section{Localização e caracterização geral dos níveis topográficos}

A área de estudo situa-se a NE de Conceição do Araguaia (49॰10` - 49 $30^{\circ} \mathrm{W}$ e $737^{`}-817^{`} \mathrm{~S}$ ) na parte sul da Amazônia Brasileira, em setor denominado de Depressão Periférica do Sul do Pará (Fig. 1).

A área encontra-se sob a ação do clima tropical úmido (1650 $\mathrm{mm}$ anuais e $22^{\circ} \mathrm{C}$ de temperatura média do mês mais frio). A litologia é composta por rochas do grupo Tocantins (ardósias, filitos, quartzitos, xistos) e intrusões de rochas ultrabásicas; todas do Pré-Cambriano (Silva et al., 1974).

A Depressão Periférica do Sul do Pará vem sendo interpretada como uma unidade morfoestrutural pediplanada pleistocênica que teria sofrido erosão fluvial posterior, originando colinas de topo aplainado que mantém traços da cobertura superficial inconsolidada (Boaventura, 1974). Essa Depressão pertence à faixa de transição entre dois domínios morfoclimáticos, onde as colinas estão revestidas por floresta densa e os relevos de topos aplainados estão cobertos por cerrado e por florestas.

$\mathrm{O}$ nível I, entre 250 e $300 \mathrm{~m}$, apresenta morfologia plana em forma de platôs cujas vertentes são retilíneas a suavemente convexas, fortemente inclinadas, e rampeadas, de menor inclinação. A rede de drenagem no topo dos platôs é incipiente, pouco densa e pouco encaixada enquanto nas encostas, que fazem a transição com o nível II, ela se torna mais densa e mais encaixada. O nível II, entre 200 e 250 m, é formado por platôs, semelhantes aos do nível I, embora a densidade de drenagem seja um pouco mais densa e as encostas, no limite com o nível III, sejam, predominantemente, rampeadas com leve inclinação e dissecação maior que no nível I. No nível III, entre 140 e $200 \mathrm{~m}$, a morfologia é de platôs e de lombadas com vertentes pouco inclinadas e densidade de drenagem alta.

Basicamente duas formas de relevo fazem parte desse conjunto topográfico: os platôs e as lombadas. 


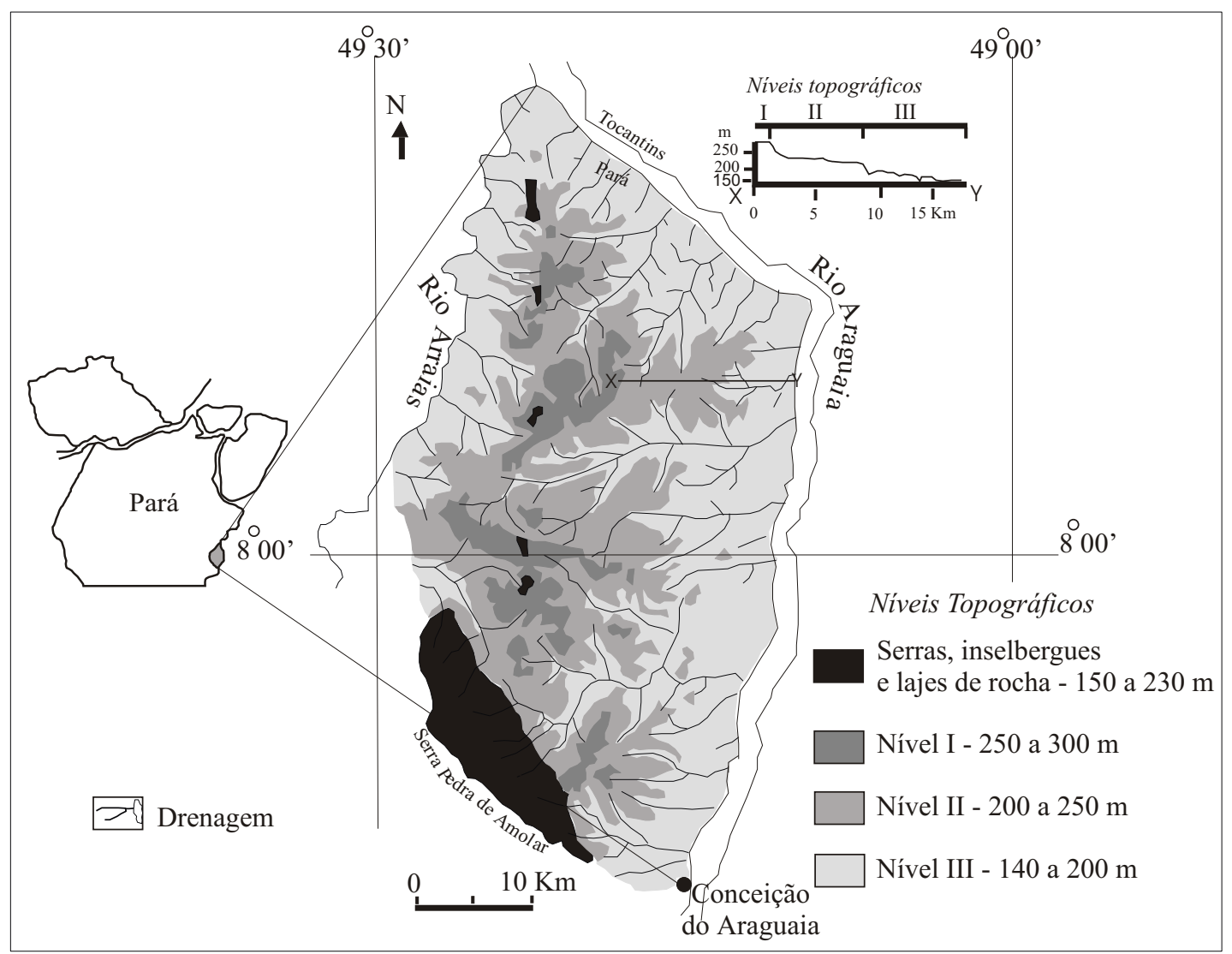

Figura 1. Localização da área de estudo e níveis topográficos

\section{Abordagem Metodológica, Procedimentos Operacionais e Resultados Cartográficos}

Três grandes conjuntos de atividades foram desenvolvidos: a) o mapeamento pedomorfológico dos relevos e os sistemas de solos associados aos relevos sobre base topográfica (IBGE, 1983 Folhas Conceição do Araguaia e Arapoema, na escala 1:100.000), b) o estudo detalhado da cobertura pedológica em campo através de toposseqüências e c) a análise laboratorial de amostras coletadas em campo, como descritos a seguir.

\section{a) Mapeamento Pedomorfológico}

Um mapa pedomorfológico objetiva compreender a distribuição espacial das coberturas pedológicas e suas relações com as diferentes formas de relevo, o que demanda estudos em diferentes escalas, da paisagem ao microscópio, enfatizando-se a caracterização macro e microscópica das coberturas pedológicas e sua organização em correspondência com as diferentes unidades de relevo.

O presente estudo da pedomorfologia do relevo deu continuidade ao trabalho anterior de Nascimento (1993). Iniciou-se pela elaboração dos seguintes mapas preliminares: drenagem/fundo de vales, declividade, lito-topográfico, comparti mentação morfológica de relevo; geomorfológico, como subsídio elaborado do pedomorfológico.

\section{Mapas Preliminares}

A carta de declividade do terreno seguiu as indicações de De Biasi (1970) e Sanches (1993) e apresenta quatro classes: $0-2,5 \% ; 2,5-10 \% ; 10-$ $25 \%$ e $>25 \%$, as quais serviram para melhor apresentar a área e apenas como referência para a delimitação de grandes conjuntos, os quais foram corroborados, posteriormente, em campo, a partir dos levantamentos das toposseqüências.

O mapa lito-topográfico, representa a relação entre a base topográfica e as litologias, tendo no mapa por referência o mapa geológico em escala 1:1.000.000 (Silva et al, 1974), e objetivou verificar a distribuição dos tipos litológicos na topografia, como auxiliar para a delimitação das unidades pedomorfológicas.

A compartimentação morfológica dos relevos baseou-se na carta de drenagem/fundo de vales e foi elaborada através da interpretação das fotos aéreas (fotografias aéreas a 1:60.000, Vôo AST 10, Ministério do Exército). Nestas foram restituídos a drenagem, os fundos dos vales, a base das vertentes e os topos, cujo organização reflete uma fisionomia em compartimentos expressos pela densidade da drenagem, extensão da vertente, largura dos topos e largura dos vales.

A dissecação horizontal revela uma relação entre a densidade de drenagem e a unidade de área e facilita o reconhecimento dos tipos de vertente, além de auxiliar na extrapolação das unidades. As classes 
estabelecidas foram: $0-0,9 \mathrm{Km} / \mathrm{Km}^{2} ; 0,9$ a 2,0 $\mathrm{Km} / \mathrm{Km} ; 2,0-2,5 \mathrm{Km} / \mathrm{Km}^{2}$

Sobre essa carta sobrepôs-se a carta litotopográfica, onde cada fisionomia foi delimitada como compartimento morfológico distinto. Deve-se ressaltar que esse mapa não tem conotação genética. As unidades delimitadas foram: 1) Platôs com vertentes pouco dissecadas a fortemente dissecadas; 2) Planos rampeados pouco dissecados; 3) Lombadas e Colinas com vertentes mediana a fortemente dissecadas; 4) Serras; 5) Fundo de vales.

Todas essas cartas foram espacialmente correlacionadas entre si para se obter a carta geomorfológica, cuja base principal foi a compartimentação morfológica do relevo. A carta geomorfológica foi elaborada, inicialmente, na escala de 1:60.000 e apresenta 5 unidades e 12 sub-unidades, apresentadas no Quadro 1, adiante.

\section{Levantamento das coberturas pedológicas}

Dois tipos de levantamentos foram realizados: um geral, de reconhecimento da distribuição espacial das coberturas pedológicas em função de níveis topográficos, dos relevos e das litologias interrelacionados nos quais se implantaram posteriormente os eixos das toposseqüências; e um detalhado, sobre área representativa.

As fases de campo e de laboratório permitiram reconhecer as diferenciações laterais e verticais das organizações pedológicas, na escala das toposseqüências e deduzir os processos de transformação. A relação das diferenciações e transformações com os resultados representados nas cartas anteriores (lito-topográfico, drenagem/ fundos de vales, clinográfico, dissecação horizontal e geomorfológico) permitiu a delimitação de unidades pedo-estruturais com apoio de fotointepretação.

Por fim, procedeu-se à compatibilização das diferentes escalas (generalização) que permitiu a obtenção das unidades cartográficas, estas de conotação genética, bem como a distinção dos processos de formação dos diferentes domínios de alteração e de pedogênese e os sistemas de transformação pedológica na paisagem. Os diversos estágios evolutivos desses sistemas conduziram às subdivisões em unidades e sub-unidades pedoestruturais de mapeamento, e possibilitaram estabelecer uma ponte entre as duas escalas de trabalho, a microscópica e a do mapeamento.

\section{Mapa Pedomorfológico}

O mapa pedomorfológico permitiu representar quatro níveis de organização (Fig. 2). O primeiro, reconhecido como o das unidades e sub- unidades pedomorfológicas, foi representado, inicialmente, na escala aproximada de 1:100.000. O segundo, o da escala das toposseqüências de campo, representa a cobertura pedológica na sua bidimensionalidade e mostra a variação das formas das vertentes em relação com as transformações laterais da cobertura pedológica.

As toposseqüências apresentadas na legenda do mapa referem-se aos principais padrões de repetição dos sistemas de solos em cada unidade pedomorfológica representativa. O terceiro nível correspondeu ao da escala dos horizontes e ilustra as diferenciações e transformações verticais e laterais das organizações elementares da cobertura pedológica em função dos processos de alteração e de pedogênese. Finalmente, o quarto nível, da microscopia óptica e eletrônica por varredura e por transmissão, ilustra as transformações na escala microscópica de organização dos materiais, isto é dos fundos matriciais e do cristal.

A legenda do mapa traz, ainda, a representação da cronologia, das interconexões e variabilidade das unidades pedomorfológicas de relevo, no tempo e no espaço, ou seja, resultando na síntese de todas as informações obtidas.

\section{em Campo \\ B) Estudo detalhado dos Sistemas de Solos \\ Esta etapa realizou-se da modo} relativamente simultâneo com a elaboração do mapa pedomorfológico.

O procedimento fundamentou-se na análise estrutural da cobertura pedológica, etapa da análise bidimensional, ao longo de eixos topográficos em campo e subseqüentemente em laboratório com base no levantamento dos sistemas de solos dispostos e representados em toposseqüências (Boulet et al, 1982 $\mathrm{a}, \mathrm{b}$ e c)

O critério para locar as diversas toposseqüências baseou-se na análise da carta topográfica que permitiu reconhecer a presença dos três níveis topográficos, já citados, e em campo, o que permitiu constatar, nas diferentes formas do relevo, a diferenciação de solos destes níveis, ao longo das vertentes e seus padrões respectivos.

Foram implantadas e estudadas em detalhe 8 toposseqüências representativas dos padrões morfológicos e estágios de evolução da cobertura pedológica na área. 
Quadro 1- Legenda da carta geomorfológica

\begin{tabular}{|c|c|c|c|c|}
\hline $\begin{array}{l}\text { UNIDADE } \\
\text { MORFOLÓGICA DE } \\
\text { RELEVO }\end{array}$ & $\begin{array}{c}\text { GERALMENTE SOBRE } \\
\text { ROCHA }\end{array}$ & $\begin{array}{l}\text { SUB-UNIDADE DE } \\
\text { RELEVO }\end{array}$ & ALTITUDE (m) & MODELADO \\
\hline \multirow{6}{*}{$\begin{array}{l}\text { Platôs com encostas pouco } \\
\text { dissecadas a fortemente } \\
\text { dissecadas }\end{array}$} & $\begin{array}{l}\text { Filitos, ardósias, xistos e, } \\
\text { as vezes, calcáreo } \\
\text { intercalado aos metapelitos }\end{array}$ & $\begin{array}{l}\text { Platôs com encostas retilíneas } \\
\text { e dissecação entre } 0 \text { e } 1 \\
\mathrm{Km} / \mathrm{Km}^{2} \text { e declividade entre } 0 \\
\text { e } 2 \%\end{array}$ & 180 a 280 & $\begin{array}{l}\text { Platôs residuais capeados } \\
\text { por couraça ferruginosa, } \\
\text { ligados a pedo-morfogênese } \\
\text { lateritizante }\end{array}$ \\
\hline & \multirow{2}{*}{$\begin{array}{l}\text { Filitos, ardósias, xistos e } \\
\text { calcáreo intercalado aos } \\
\text { metapelitos }\end{array}$} & $\begin{array}{l}\text { Platôs com dissecação entre } 0 \\
\text { e } 1 \mathrm{Km} / \mathrm{Km} \text { e declividade } \\
\text { entre } 0 \text { e } 2 \% \text { com encosta } \\
\text { retilínea de inclinação entre } 10 \\
\text { e } 25 \%\end{array}$ & 220 a 280 & \multirow{9}{*}{$\begin{array}{l}\text { Relevos originados pelas } \\
\text { mudanças no sistema pedo- } \\
\text { morfogenético com } \\
\text { evolução das encostas e } \\
\text { instalação da drenagen de } \\
\text { ordem inferior sobre os } \\
\text { antigos platôs }\end{array}$} \\
\hline & & $\begin{array}{l}\text { Platôs com dissecação entre } 0 \\
\text { e } 1 \mathrm{Km} / \mathrm{Km}{ }^{2} \text { e declividade } \\
\text { entre } 0 \text { e } 2 \% \text { com encos ta } \\
\text { rampeada de inclinação entre } 2 \\
\text { e } 4 \%\end{array}$ & 220 a 280 & \\
\hline & \multirow{2}{*}{ Filitos, ardósias e xistos } & $\begin{array}{l}\text { Platôs com dissecação entre } 0 \\
\text { e } 2 \mathrm{Km} / \mathrm{Km}^{2} \text { e declividade } \\
\text { entre } 0 \text { e } 2 \% \text { com encosta } \\
\text { rampeada de perfil irregular } \\
\text { com inclinação entre } 2 \text { e } 4 \%\end{array}$ & 170 a 250 & \\
\hline & & $\begin{array}{l}\text { Encostas convexo-retilíneo- } \\
\text { côncavas com dissecação entre } \\
0 \text { e } 2,5 \mathrm{Km} / \mathrm{Km}^{2} \text { e declividade } \\
\text { entre } 2 \text { e } 6 \%\end{array}$ & 170 a 210 & \\
\hline & $\begin{array}{l}\text { Filitos, ardósias, xistos e, } \\
\text { as vezes, calcáreo } \\
\text { intercalado aos metapelitos }\end{array}$ & Inselbergues & $>220$ & \\
\hline \multirow[t]{2}{*}{$\begin{array}{l}\text { Planos rampeados pouco } \\
\text { dissecados }\end{array}$} & \multirow[t]{2}{*}{ Filitos, ardósias e xistos } & $\begin{array}{l}\text { Planos rampeados com } \\
\text { dissecação entre } 0 \text { e } 2 \mathrm{Km} / \mathrm{Km}^{2} \\
\text { e declividade entre } 0 \text { e } 2,5 \%\end{array}$ & 145 a 180 & \\
\hline & & Inselbergues & 170 a 220 & \\
\hline \multirow[t]{2}{*}{$\begin{array}{l}\text { Lombadas e colinas com } \\
\text { encostas medianamente a } \\
\text { fortemente dissecadas }\end{array}$} & \multirow{2}{*}{ Filitos, ardósias e xistos } & $\begin{array}{l}\text { Lombadas com encostas } \\
\text { convexas com dissecação entre } \\
0,9 \text { e } 2,5 \mathrm{Km} / \mathrm{km}^{2} \text { e } \\
\text { declividade entre } 2 \text { e } 8 \% \\
\end{array}$ & 171 a 221 & \\
\hline & & $\begin{array}{l}\text { Colinas com encostas } \\
\text { convexas com dissecação entre } \\
0,9 \text { e } 2,5 \mathrm{Km} / \mathrm{Km}^{2} \mathrm{e} \\
\text { declividade entre } 3 \text { e } 15 \% \\
\end{array}$ & 195 a 241 & \\
\hline Serras & $\begin{array}{l}\text { Quartzitos até xistos-filitos } \\
\text { intercalados por lentes de } \\
\text { rochas ultrabásicas }\end{array}$ & $\begin{array}{l}\text { Cristas, encostas e espigões } \\
\text { das serras, inselbergues e lajes } \\
\text { de rocha com solos litólicos, } \\
\text { depósitos detríticos de encosta } \\
\text { e afloramento de rocha. } \\
\text { Dissecação entre } 0 \text { e }>2,5 \\
\mathrm{Km} / \mathrm{Km}^{2} \text {; declividade entre } 0 \\
\text { e } 2,5 \text { e entre } 10 \text { e }>25 \% \\
\end{array}$ & $\begin{array}{l}\text { - Lajes de rocha: a } \\
\text { aproximadamente } 150 \\
\text { - Serras e inselbergues: > } \\
230\end{array}$ & $\begin{array}{l}\text { Relevos influênciados pela } \\
\text { estrutura, modelados a partir } \\
\text { da instalação da drenagem } \\
\text { de primeira e segunda } \\
\text { ordem e por processos de } \\
\text { erosão das encostas. }\end{array}$ \\
\hline Fundo de vales & Indiscriminada & Planícies de inundação & $140 \mathrm{a}>250$ & $\begin{array}{l}\text { Planícies modeladas a partir } \\
\text { da deposição de sedimentos } \\
\text { fluviais ou pela simples } \\
\text { instalação da drenagem } \\
\text { sobre antigos platôs } \\
\text { encouraçados }\end{array}$ \\
\hline
\end{tabular}




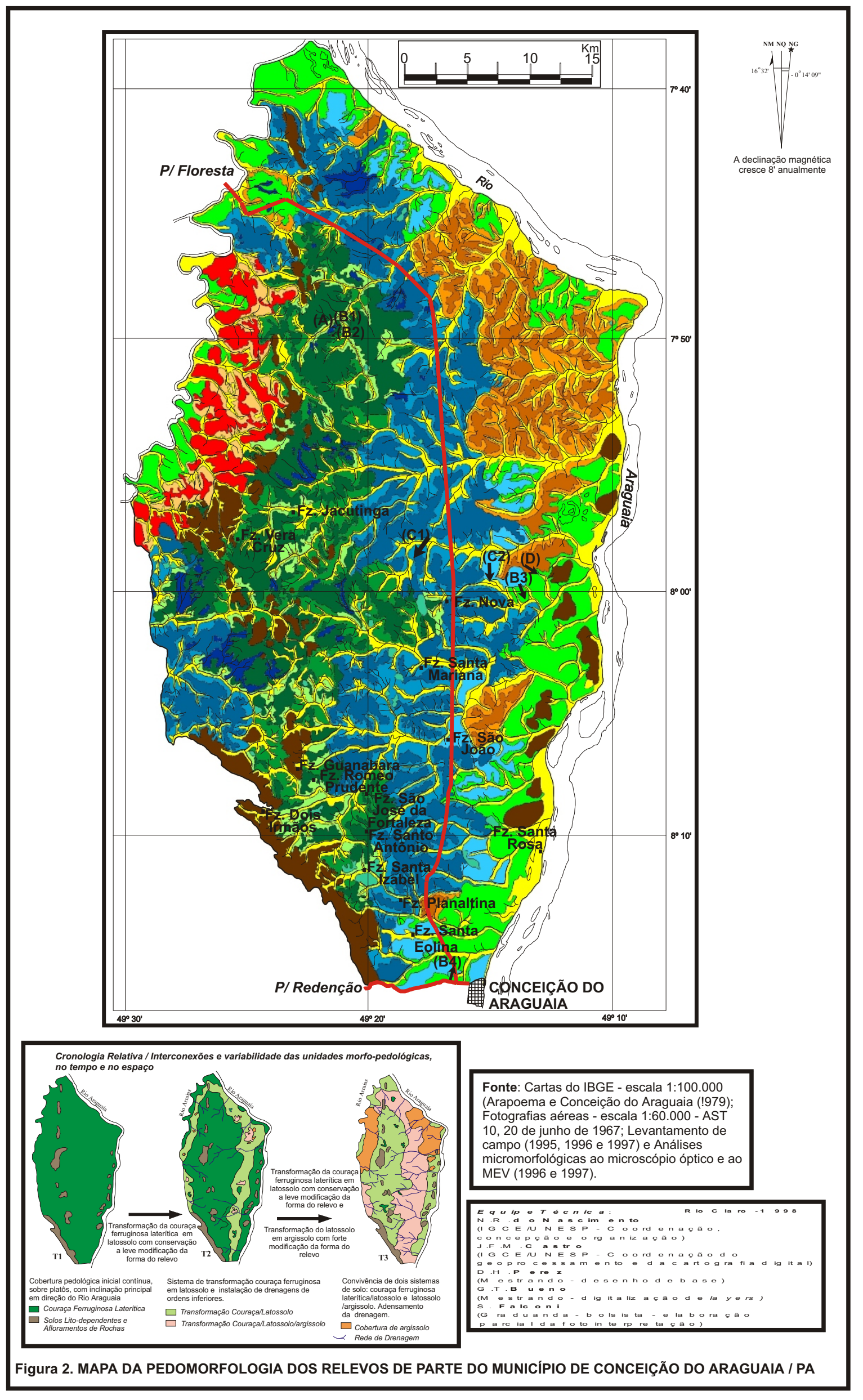




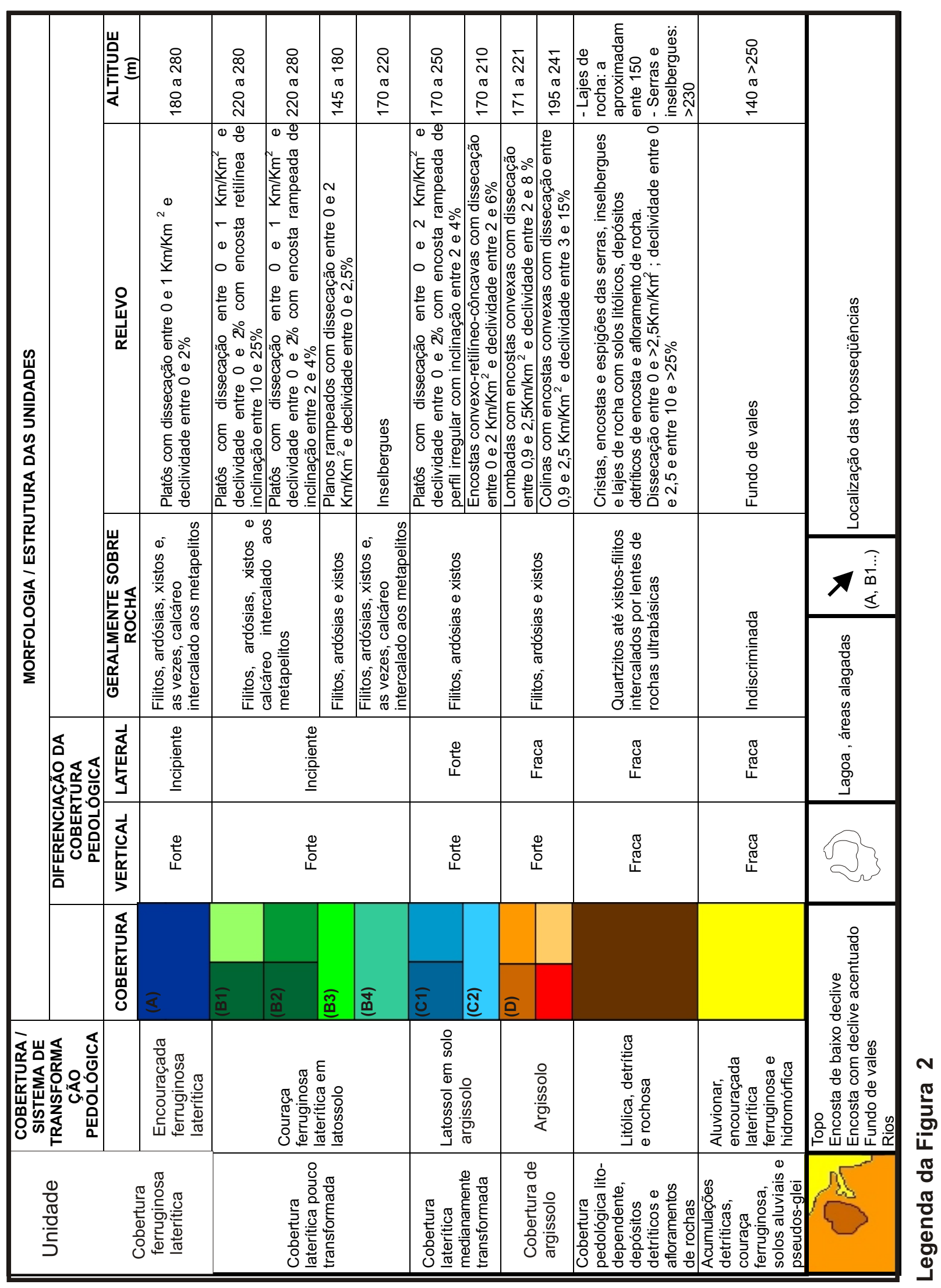




\section{C) Caracterização analítica dos sistemas de solos}

O estudo das toposseqüências foi complementado por análises de laboratório sobre amostras coletadas prioritariamente nas unidades que se constituíam em domínios representativos dos processos pedo-morfogenéticos identificados em campo.

As amostras deformadas (friáveis) e indeformadas destinaram-se às análises granulométricas, químicas, mineralógicas e micromorfológicas por microscopia óptica e por eletrônica de varredura e transmissão e microquímicas (análise química pontual), cujos métados são descritos a seguir:

1 - Análise granulométrica para caracterização textural Camargo et al. (1986)

2- Análises químicas globais por fluorescência de raios X com equipamento Philips PW 2510 Sampler Changer para detectar os elementos maiores como $\mathrm{K}, \mathrm{Na}, \mathrm{Ca}, \mathrm{Si}, \mathrm{Al}, \mathrm{Fe}, \mathrm{Mg}$, entre outros, com vistas a compreender a evolução geoquímica dos materiais.

3- Análises mineralógicas da fração argila por difração de raios $\mathrm{X}$, utilizando-se de um equipamento Philips Diffractometer e PW 3710 Goniometer, sob as condições de $40 \mathrm{kV}, 30 \mathrm{~mA}, \mathrm{Cu}-\mathrm{Ka}$ radiation, scanning rate of $1.2 \mathrm{q} / \mathrm{mm}$, para identificação dos minerais presentes.

4- Estudo micromorfológico de amostras previamente preparadas e coladas em lâminas delgadas, com microscópio óptico do tipo Zeiss, utilizando-se recomendações, conceitos e termos propostos por Brewer (1976); destacou-se as observações relativas ao fundo matricial, em especial quanto ao comportamento e natureza do plasma e dos poros, bem como das feições pedológicas; ressaltou-se as transições, as hierarquias e cronologias relativas entre os constituintes e suas organizações, o que permitiu a reconstituição das evoluções microestruturais e mineralógicas dos materiais, bem como a seleção das amostras e dos pontos sobre os quais foram efetuadas as análises microquímicas.

5- Análises morfológicas e microquímicas sob microscópio eletrônico de varredura (MEV) e sonda eletrônica com sistema EDS (equipamento Cambridge S 200 e Jeol - JMS-T 330A). Essas análises permitiram levantar hipóteses, dentre as quais algumas foram comprovadas a partir de análises sob o microscópio eletrônico por transmissão (MET).

Dentre as oito toposseqüências estudadas, a C2, situada na transição entre os níveis topográficos II e III (Fig 2), bem marcada por vertentes convexoretilíneo-côncavas foi escolhida para ilustrar este trabalho por conter todos os domínios representativos de evolução pedomorfológica da área como um todo.

\section{Domínios Estruturais da Toposseqüência representativa $\mathrm{C} 2$.}

O sistema de solos exposto nessa toposseqüência distribui-se ao longo de um segmento retilíneo a levemente convexo, na montante; convexo, na parte superior do terço médio da vertente e côncavo na jusante. Mostra cinco domínios estruturais e mineralógicos representados na Figura 3 A e B: 1) de alteração da rocha; 2) maciço ferruginoso duro (couraça ferruginosa); 3) latossólico que aparece indistintamente acima dos anteriores; 4) argiloso/ hidromórfico e lixiviado/pedregoso. Pode-se perceber uma certa simetria na disposição desses domínios estruturais de montante a jusante.

Os horizontes do domínio estrutural de alteração são contínuos e mergulham na direção de jusante. Sobre eles, na montante, aparecem os horizontes maciços ferruginosos duros do domínio estrutural da couraça ferruginosa, em forma de cunha, que mergulham na direção de jusante e estão em discordância com os horizontes do domínio argiloso/hidromórfico. $\mathrm{Na}$ jusante os horizontes maciços ferruginosos, duros/protopsolíticos do domínio da couraça ferruginosa, apresentam forma de cunha projetada na direção de montante. Igualmente são discordantes com aqueles do domínio estrutural argiloso/hidromórfico.

Este domínio, posicionado no terço médio da toposseqüência, assenta-se diretamente sobre a alteração da rocha, o que sugere que o argiloso/hidromórfico é posterior à couraça ferruginosa e origina-se dela.

Tanto à montante como à jusante o domínio estrutural latossólico assenta-se sobre o da couraça ferruginosa e sobre o argiloso/hidromórfico.

O latossólico apresenta-se em forma de cunha, cujas extremidades posicionam-se opostas uma da outra e estão voltadas para o meio da toposseqüência. Já o domínio lixiviado/pedregoso é discordante tanto com o latossólico de montante e de jusante como com o argiloso/hidromórfico.

Essa geometria permitiu supor que o latossolo desenvolveu-se a partir da couraça ferruginosa e do domínio estrutural argiloso/hidromórfico. No entanto, o fato de todos serem cortados pelo lixiviado/pedregoso indica que este último pode ter sua origem a partir dos primeiros.

A presença da couraça ferruginosa na montante e na jusante da toposseqüência, separada pelo domínio latossólico, faz supor a presença de um sistema de transformação sobre a couraça, que antes era mais supostamente contínua, uma vez que o domínio lixiviado /pedregoso sendo discordante em relação aos domínios estruturais latossólico e argiloso/hidromórfico, faz supor que o lixiviado/ pedregoso é o resultado de um processo de perda dos materiais finos que levou à acumulação relativa do material grosseiro.

\subsection{Domínio de Alteração da Rocha}

Dois horizontes foram observados, ambos cortados por veios de quartzo. O da base apresenta textura saprolítica fina, mas já desenvolve estrutura em pequenos blocos angulares cuja textura dos materiais é silto-argilosa e se justapõem; a sua cor é heterogênea (vermelha, 2,5YR4/8; vermelha escura, 2,5YR3/6; amarelo-brunada, 10YR6/6), enquanto a mineralogia dessas fases é homogênea e composta por caolinita, goetita, hematita, clorita e sericita (Fig. 3B). 
Deve-se ressaltar que, distribuídas por toda a região ao longo dos vários vales fluviais da bacia do Araguaia, aparece a unidade das coberturas aluvionares encouraçadas lateríticas ferruginosas e hidromórficas. Essas couraças podem formar o piso dos rios de ordens inferiores; e que essas coberturas são encontradas sobre qualquer tipo de rocha, em altitudes que variam dos $250 \mathrm{~m}$, próximo às nascentes, até 140 $\mathrm{m}$, junto do nível de base regional (Rio Araguaia). A diferenciação lateral e vertical dessas coberturas é fraca.

O do topo é composto por pequenos blocos angulares mais porosos e friáveis que no nível subjacente e por plaquetas e nódulos ferruginosos. Os blocos angulares não apresentam nenhum traço de ferruginização e endurecimento que indique um processo de acumulação do ferro, mas, o amarelecimento do plasma sugere uma relação com os efeitos da saturação hídrica temporária. As plaquetas correspondem a nódulos ferruginosos litoreliquiais do filito, constituidas por goetita e hematita, além de traços de caolinita e sericita, e não apresentam nenhuma relação com os blocos. São duras e apresentam estrutura petrográfica em bandas. Os nódulos ferruginosos são arredondados, com a mesma mineralogia que as plaquetas e não apresentam a estrutura da rocha.

Ao microscópio óptico os blocos angulares constituem dois fundos matriciais com estrutura de base porfirosquélica: um é bruno-avermelhado, opaco e o outro é amarelo-brunado claro, anisotrópico, com plasma massépico e cutãs de estresse na vizinhança

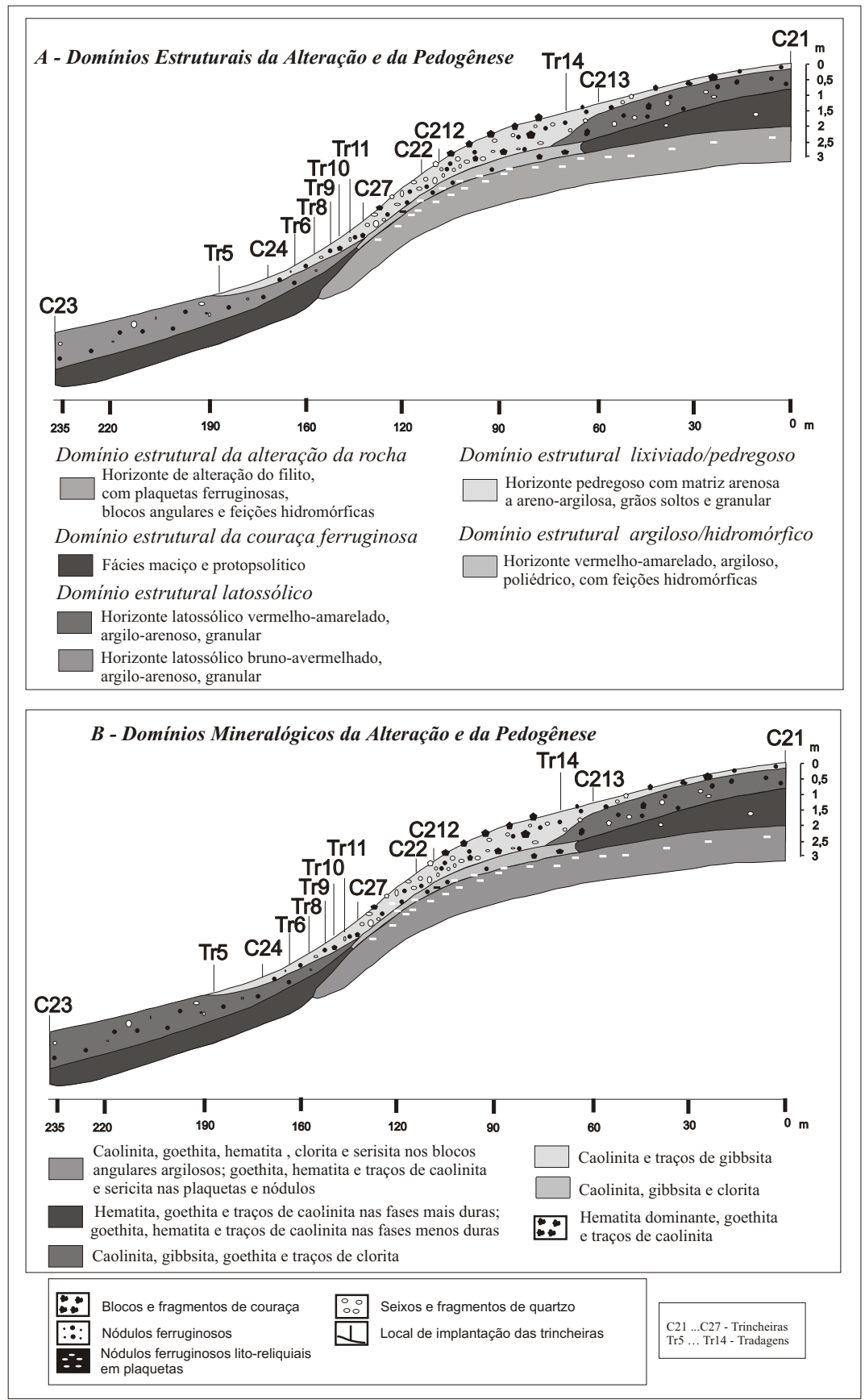

Figura 3. Domínios estruturais e mineralógicos da alteração e da pedogênese 
dos nódulos (LN). Esse último fundo matricial é dominante sobre o primeiro. Os nódulos são alongados em forma de plaquetas; arredondados e mistos.

Os nódulos em plaquetas apresentam plasma opaco em bandas bruno muito escuras e brunoavermelhadas escuras, ou são homogêneos com diferenciação periférica de cor bruna. Os plasmas mais escuros estão sempre em discordância com os mais claros que tendem a dominar e generalizar-se, confundindo-se com o fundo matricial adjacente aos nódulos. Os arredondados diferem das plaquetas pela quantidade e tamanho do esqueleto ( $15 \%$ do fundo matricial do nódulo), têm diâmetros entre 1 e $5 \mathrm{~mm}$, plasma de cor bruna, bruno-avermelhada e vermelha escura (LN) e são opacos (LP). Os mistos aparecem em menor quantidade e são constituídos pela união dos outros dois tipos. É nítida a diferenciação entre as duas partes: uma de estrutura em bandas, com esqueleto fino distribuído segundo as bandas e outra, contínua, com esqueleto mais abundante e mais grosseiro, distribuído aleatoriamente. $\mathrm{O}$ fundo matricial que compõe os blocos angulares é discordante sobre os fundos matriciais dos nódulos.

A ausência da estrutura da rocha nos blocos angulares mostra que os nódulos ferruginosos não se formam a partir da fase argilosa dos blocos, mas, da rocha sã. O plasma massépico e os cutãs de estresse indicam relação com saturação hídrica. $O$ fato de se ter nódulos em plaquetas, bandeados, litoreliquiais, pouco quartzosos e de se ter nódulos arredondados muito quartzosos mostra que estes últimos não evoluem a partir dos primeiros. A presença desses nódulos mistos ressalta a diferenciação morfológica entre as plaquetas e os arredondados e evidencia que eles se formaram ao mesmo tempo e que sua, diferenciação está relacionada com a estrutura da própria rocha, ou seja, nas bandas com texturas finas, pouco quartzosas, desenvolvem-se os nódulos em plaquetas, bandados; nas bandas atravessadas por veios de quartzo, desenvolvem-se os nódulos arredondados.

A discordância entre o fundo matricial que compõe os blocos angulares e aquele dos nódulos comprova que a alteração argilosa relaciona-se, também, com a deferruginização dos nódulos, uma vez que a mineralogia é a mesma, tanto nos blocos como nos nódulos. Assim, a alteração ferruginosa pode ter sido isalterítica e reliquial e a argilosa, aloterítica e atual.

Em direção do topo aumenta a quantidade de nódulos ferruginosos e passa-se gradualmente ao domínio estrutural argiloso/hidromórfico, na média vertente, e abruptamente ao domínio estrutural da couraça, na montante e na jusante (Fig. 3A).

\subsection{Domínio Estrutural Argiloso/Hidromórfico}

A passagem do domínio subjacente para este é marcada pela generalização da matriz argilosa em blocos, pela diminuição do número e tamanho dos nódulos ferruginosos em forma de plaquetas e pelo aumento dos nódulos arredondados.

No nível macroscópico esse horizonte apresenta uma matriz de cor vermelho-amarelada (5YR5/8), entre a tradagem $\operatorname{Tr} 14$ e a trincheira C212, e bruna-amarelada (10YR6/8), entre C212 e Tr11 (Fig. $3 \mathrm{~A}$ ); uma textura argilosa, uma estrutura em blocos angulares (poliédrica) e uma porosidade estrutural dominante (fissuras). A mineralogia da fração argila mostra uma composição basicamente caolinítica, gibbsítica e clorítica (Fig. 3B). Nos poliedros, a matriz argilosa engloba nódulos arredondados e mamelonares bruno-amarelados, vermelho escuros e bruno-avermelhado escuros e nódulos litoreliquiais.

No nível microscópico constatou-se a presença de duas zonas: uma matricial amarelobrunado claro que corresponde aos blocos angulares e outra nodular. A estrutura de base dos dois é porfirosquélica. O fundo matricial amarelo-brunado claro contem um esqueleto quartzoso com diâmetros que variam desde a fração areia fina até cascalho. Eles são fissurados e ferruginizados na maior parte e ocupam aproximadamente $10 \%$ da área desse fundo matricial. Os poros são representados por fraturas e cavidades com paredes mais ou menos irregulares, interconectados. O plasma é amarelo-brunado claro em LN com anisotropia vo-insépica e com cutãs de estresse (LP).

Esse fundo matricial amarelo-brunado claro é discordante com os nódulos. Estes são ferruginosos, em forma de plaquetas e revelam características semelhantes àqueles da alteração da rocha, enquanto os arredondados aumentam em quantidade e tamanho. Os nódulos ferruginosos arredondados apresentam cor bruna, bruna-amarelada, bruno-avermelhada e vermelha muito escura (LN). Os plasmas são opacos (LP) e alguns deles apresentam uma borda de descoloração, de cor mais clara do que o núcleo, que demonstra a sua diferenciação.

A presença de nódulos ferruginosos em forma de plaquetas litoreliquiais indica que este domínio estrutural se desenvolve a partir do domínio de alteração. $\mathrm{O}$ fundo matricial dos blocos angulares é discordante sobre os nódulos litoreliquiais em plaquetas e arredondados o que comprova que esse domínio vem da deferruginização de uma fase mais ferruginosa (couraça ?), e da alteração da rocha. O plasma vo-insépico e os cutãs de estresse são indicativos de que essa alteração se processa em ambiente hidromórfico.

Este domínio estrutural argiloso/ hidromórfico faz limite diretamente com o lixiviado/pedregoso.

\subsection{Domínio Estrutural da Couraça Ferruginosa}

A passagem do domínio de alteração para o domínio da couraça é abrupta e marcada por um endurecimento da matriz que configura um horizonte maciço. Nada indica que essa matriz endurecida evoluiu a partir daquela dos blocos angulares uma vez que esta não traz nenhum traço de ferruginização. A hipótese levantada é de que a couraça seria parte da seqüência responsável pela formação dos nódulos ferruginosos.

Os horizontes da couraça têm aspecto maciço e apresentam diferenciações constituídas por fases mais duras e menos duras, ferruginizadas, que se 
fragmentam em blocos. As fases duras tem cor brunoavermelhada escura (2,5YR3/4, a montante, e 5YR4/4 a jusante) com hematita e goethita dominantes e traços de caolinita (Fig.3B e 4).

As fases menos duras são vermelha escura (2,5YR3/6) com goethita dominante, hematita e traços de caolinita, e bruno-amarelada (10YR6/8, na montante e 10YR5/8, na jusante), com goetita dominante, caolinita e traços de hematita (Fig. 3B e 4). Na jusante essa matriz é menos dura, argilo-arenosa e envolve nódulos ferruginosos, mamelonares, duros.

Tanto na montante como na jusante as duas fases apresentam-se justapostas, sendo que aquelas mais duras assumem forma mamelonar como se fossem nódulos e estão sempre interpenetradas pelas fases menos duras. Na matriz maciça ferruginosa há fragmentos de quartzo, arredondados e angulares, de diâmetro do milímetro até vários centímetros ( 3 a 5 $\mathrm{cm})$.

Uma fase móvel, porosa e granular, discordante com a matriz maciça ferruginosa, anuncia a transformação desta última. A fase móvel, de cor bruna escura (7,5YR4/6), a montante, e amarelobrunada (10YR6/6) a jusante, é composta por caolinita dominante, goethita e gibbsita e traços de hematita e clorita (Fig 3B) e guarda no seu interior pequenos blocos, semelhantes à matriz maciça dura, além de nódulos ferruginosos mamelonares, parecidos com aqueles do domínio estrutural argiloso/hidromórfico, e fragmentos de quartzo. Na direção do topo essa fase móvel é dominante sobre as feições ferruginosas.

Ao microscópico óptico, na montante, a matriz ferruginosa, dura, apresenta fundo matricial bruno-amarelado escuro, muito denso e contínuo. A micrografia ao MEV mostra que localmente o plasma constitui-se de hematita (Fig.4).

A fase móvel apresenta fundo matricial amarelo-brunado, goetítico e caolinítico (Fig. 3B), discordante com o bruno-amarelado-escuro. Ambos os fundos matriciais apresentam estrutura porfiroesquélica, embora na fase móvel ocorram estruturas aglomeroplásmicas. $\mathrm{Na}$ matriz maciça os agregados são nitidamente delimitados. Do centro para a periferia dos agregados passa-se do brunoamarelado ao vermelho escuro. Essa diferenciação justapõe diferentes fases ferruginosas, sendo que, durante $o$ processo de transformação, as mais ferruginizadas permanecem no centro dos agregados e têm aspecto de nódulos mamelonares. O esqueleto, em proporção de $5 \%$, é composto por fragmentos de quartzo do diâmetro da areia fina até o centímetro. Os poros são do tipo cavidades e fissuras interagregados e transagregados que atravessam, também, o fundo matricial amarelo-brunado adjacente, mostrando que esta porosidade é posterior à diferenciação ferruginosa.

Na fase móvel há o incremento do esqueleto, se comparado com o da matriz maciça, que ocupa $15 \%$ do fundo matricial. Os poros aparecem em maior quantidade e são mais largos. O plasma, nitidamente deferruginizado, tem cor amarela-brunada (LN). Esse fundo matricial é discordante com todas as diferenciações ferruginosas do fundo matricial da matriz maciça de tal maneira que volumes desse último, como se fossem nódulos, ficam envolvidos pela fase móvel.

$\mathrm{Na}$ jusante, ao microscópio óptico, são observados duas zonas: uma matricial e outra nodular, aproximadamente na mesma proporção. O matricial é composto por três fundos matriciais: um brunoamarelado escuro e outro amarelo-brunado, semelhantes aos de montante, e um amarelo claro (LN) (Fig. 4). O amarelo claro é discordante com o amarelo-brunado, é dominante e apresenta estruturas de base porfirosquélica e aglomeroplásmica, que sob aumento de 20X mostra domínios microagregados. O esqueleto ocupa $15 \%$ do fundo matricial. O plasma amarelo claro (LN) é silasépico (LP). Trata-se de um plasma caolinítico/gibbsítico e ferruginoso, microcristalino (Fig. 4). A zona nodular contem nódulos com diâmetros do milímetro ao centímetro, de cores bruno-amarelada, bruno-avermelhada e bruno muito escura, goethítico e hematítico (Fig. 4). Nos nódulos mais escuros o esqueleto é mais abundante do que nos mais claros. Os nódulos escuros possuem diferenciação periférica bruno-amarelada com leve anisotropia em bandas paralelas à superfície do nódulo, interpretadas como fantasmas das bandas das plaquetas ferruginosas.

Nessa diferenciação o plasma é goethítico e caolinítico (Fig. 4). Sob aumento de 20X pode-se observar: 1) gradação desde a cor escura que corresponde ao núcleo do nódulo, até a cor bruno-amarelada da borda; 2) grãos do esqueleto são compartilhados na parte interna, mais escura, e na parte externa, mais clara. Isso indica a deferruginização dos nódulos.

O fato do domínio estrutural da couraça apresentar, na sua base, diferenciações ferruginosas dentro de uma matriz contínua dura indica a presença de uma fácies maciça de uma couraça ferruginosa que poderia ter existido no nível do domínio argiloso/hidromórfico uma vez que aí existem nódulos semelhantes aos da couraça. Uma diferenciação nodular já é observada na matriz maciça o que anuncia a passagem da fácies maciça para a protopsolítica.

Em direção do topo desse domínio estrutural a fase móvel argilo-arenosa granular é discordante com a couraça. No nível microscópico essa discordância foi confirmada e demonstra que a fase móvel é posterior e transforma a couraça, portanto, a diferenciação nodular no interior desta última não mais se processa. Por outro lado, a fase móvel domina sobre os nódulos, no topo desse domínio estrutural, o que indica que ela transforma, também, os nódulos. Isso corrobora a interpretação de que a couraça não está mais se formando, mas que ela subsiste a um processo de deferruginização.

Assim, duas vias seriam responsáveis para a formação dos protopsólitos: a primeira, reliquial, que desenvolveu a partir da diferenciação no seio da couraça e uma outra, atual, que desenvolve pela deferruginização das matrizes ferruginosas. $\mathrm{O}$ fato de haver semelhanças entre a fácies maciça/ protopsolítica de jusante com a de montante indica forte possibilidade de ter se tratado de uma mesma couraça ferruginosa que tinha continuidade em toda a toposseqüência e que sofreu transformações posteriores. 
Em direção do topo alarga-se a porosidade e a fase móvel progride sobre a fase ferruginosa que se fragmenta em blocos cada vez menores. No nível microscópico, a estrutura de base aglomeroplásmica torna-se dominante e o esqueleto do fundo matricial chega a $25 \%$. Passa-se gradualmente para o domínio estrutural latossólico.

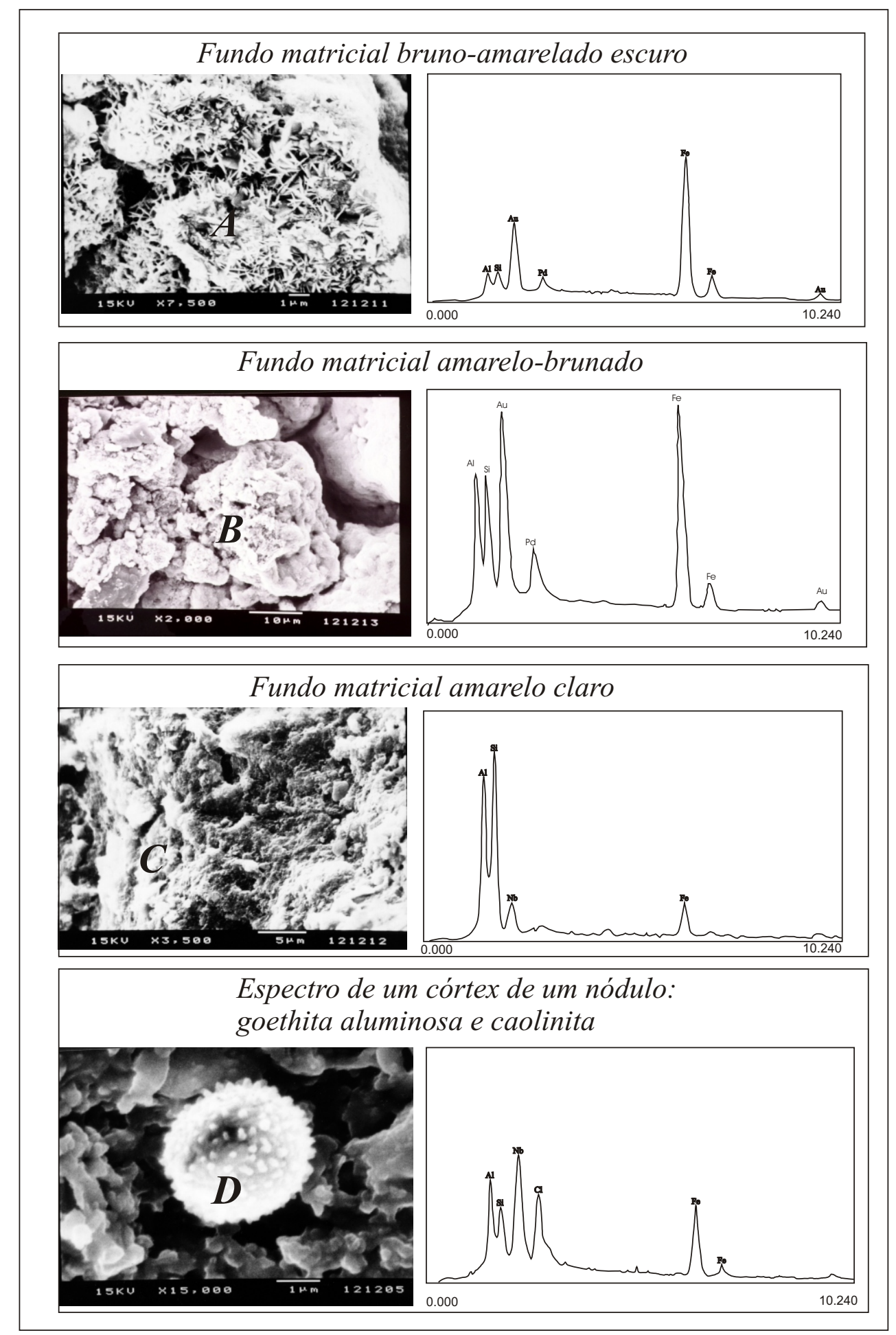

Figura 4. Micrografias ao MEV e espectros ao EDS na transição couraça/latossolo.

Observam-se a dominância de ferro nas formas de hematita (A), na fase bruno-amarelada escura, e de goethita (B), na fase amarelo-brunada, e a diminuição desse elemento, na fase amarela clara, a medida que a couraça se deferruginiza, formando um plasma microcristalino composto por caolinita e gibbsita (C). Nessa mesma transição destaca-se a presença de um nódulo de goethita aluminosa (D). 


\subsection{Domínio Estrutural Latossólico}

Este domínio é composto pela fase móvel, por pequenos blocos ferruginosos e por nódulos ferruginosos mamelonares. A matriz é bruna escura (7,5YR4/6), a montante, e amarelo-brunada (10YR6/6), a jusante; é argilo-arenosa e granular e apresenta uma composição mineralógica de caolinita dominante, gibbsita, goethita e traços de clorita (Fig. 3B). Os nódulos ferruginosos mamelonares têm diâmetro de até $5 \mathrm{~cm}$. Eles são bruno-amarelados (10YR6/8) com goethita dominante, caolinita e traços de hematita; vermelho escuros $(2,5 \mathrm{YR} 3 / 6)$ com goethita dominante, hematita e traços de caolinita e bruno-avermelhado escuros $(2,5 \mathrm{YR} 3 / 4)$ com hematita e goethita dominantes e traços de caolinita; ou formados pela justaposição das três fases. A mineralogia desses nódulos é semelhante àquela das fases ferruginosas da matriz maciça.

Em direção do topo os nódulos e fragmentos de quartzo generalizam-se enquanto a matriz fina diminui. Começam a aparecer nódulos vermelhos muito escuros com uma grande quantidade de esqueleto $(25 \%)$, que se diferenciam dos anteriores por terem hematita dominante e traços de caolinita.

No nível microscópico observa-se um fundo matricial que corresponde à fase móvel e nódulos. $\mathrm{Na}$ fase móvel é amarelo-brunado (LN), a montante, e amarelo claro (LN), a jusante; na base do domínio predominam as estruturas porfirosquélica e localizadamente as aglomeroplásmicas, a montante; e aglomeroplásmicas e microagregada sob aumento 20X, a jusante. O esqueleto é constituído por fragmentos de quartzo (aproximadamente $25 \%$ ) do fundo matricial. A porosidade é alta e constituída por cavidades de formas irregulares e tamanhos variados, às vezes ligadas entre si.

O plasma, amarelo-brunado (LN), na montante, e amarelo claro (LN), na jusante, é silasépico (LP), mas, localizadamente, é vossépico. A quantidade de esqueleto e de vazios nessas áreas de plasma vossépico é um pouco menor que no resto desse fundo matricial.

No topo, nesse fundo matricial, a quantidade de esqueleto passa a ocupar $40 \%$ da lâmina a montante e $35 \%$ a jusante. O plasma, ao contrário, diminui e torna-se um pouco mais bruno, por influência da matéria orgânica. Convivem ao mesmo tempo estruturas de base porfirosquélica, aglomeroplásmica e granular, e aumenta a quantidade de poros. Os nódulos, bruno-amarelados, brunos, brunoavermelhados e vermelhos muito escuros, opacos (LN), são constituídos por hematita, goethita e caolinita associada, sendo que nos mais escuros aumenta a proporção de hematita.

Esses dois últimos tipos apresentam maior quantidade de esqueleto quartzoso $(>10 \%)$ e, às vezes, uma diferenciação periférica bruno-amarelada forte. $\mathrm{Na}$ montante, as amostras em lâminas mais próximas do topo do domínio estrutural, o fundo matricial amarelo-brunado está restrito a alguns aglomerados. Os nódulos são dominantes, sobretudo os mais escuros, e o esqueleto quartzoso é abundante. Nessas lâminas aparecem nódulos com fundo matricial vermelho muito escuro, cujo esqueleto quartzoso alcança $25 \%$ da área.

A similaridade entre os materiais ferruginosos presentes na couraça com aqueles do domínio latossólico e as relações geométricas entre a fase móvel do latossolo com as feições ferruginosas permite concluir que o domínio estrutural latossólico provém da alteração da couraça.

Por outro lado, dentro desse domínio observa-se uma diminuição gradual do número e do tamanho dos nódulos e da fração fina. Isso permite supor que: 1) a couraça ocorria até o nível do latossolo e que os nódulos constituem uma relíquia e, 2) esse domínio estrutural latossólico está sofrendo uma perda da fase fina que poderia levá-lo a formar horizontes pedregosos.

As observações microscópicas mostram que a partir da fase móvel, que é discordante com a couraça, até a fase móvel do latossolo, o fundo matricial passa de uma estrutura de base porfirosquélica e aglomeroplásmica para a granular no topo do domínio estrutural latossólico. O plasma passa de vossépico a insépico e, posteriormente, a silassépico e a porosidade aumenta.

Essas diferenciações indicam, sobretudo, a reorganização desse fundo matricial. No entanto, a diminuição do plasma seguida do aumento da quantidade de esqueleto faz supor que há uma perda ou destruição deste plasma. Os nódulos da couraça são reliquiais, mas continuam a ser transformados pela deferruginização neste domínio estrutural. Por outro lado, no topo deste domínio aparecem nódulos vermelho muito escuros com grande quantidade de esqueleto quartzoso $(25 \%)$ que parecem constituir uma descontinuidade dentro da toposseqüência. A presença desses nódulos permite levantar a hipótese de que eles são a herança da fácies protopsolítica da couraça ferruginosa.

A transição para o domínio estrutural lixiviado/pedregoso se dá de forma gradual e é marcada por uma diminuição da matriz fina e pelo aumento, em proporção, dos nódulos e fragmentos de quartzo.

\subsection{Domínio estrutural lixiviado/ pedregoso}

A passagem do domínio estrutural argiloso/hidromórfico para este lixiviado/pedregoso é abrupta e marcada por um limite mamelonar.

No nível macroscópico este domínio estrutural é composto por uma fração grosseira dominante sobre uma fase fina. A fração grosseira é constituída por nódulos ferruginosos, fragmentos de quartzo e por blocos grandes de couraça ferruginosa. $\mathrm{Na}$ fração grosseira os nódulos são mamelonares, como os do domínio estrutural latossólico, e arredondados de cor vermelha muito escura, muito quartzosos, já identificados na parte superior do domínio estrutural latossólico. Nessa mesma fração grosseira, blocos de couraça ferruginosa são muito duros (só quebram com ajuda do martelo) e têm diâmetro decimétrico; outros estão tão alterados e se desfazem em pequenos nódulos dentro de uma matriz fina. Os nódulos desses blocos são vermelhos muito 
escuros, muito quartzosos e apresentam diferenciações mais claras do que o vermelho muito escuro. Nos blocos duros eles são englobados por uma matriz ferruginosa muito dura.

A fase fina, de cores bruno-acinzentada escura (10YR4/2), cinza muito escura (10YR3/1) a preta (10YR2/1) na superfície, composta por caolinita dominante e gibbsita (Fig. 3B), tem estrutura granular e textura silto-arenosa devido à matéria orgânica. $\mathrm{Na}$ superfície deste domínio estrutural a fração grosseira forma uma camada contínua sem fração fina. Essa fração grosseira é dominante e apresenta blocos ferruginosos de até 25 centímetros de diâmetro, duros, como restos da fácies protopsolítica da couraça. Esses blocos têm muitas feições de dissolução e envolvem inúmeros fragmentos de quartzo.

Nas lâminas das amostras da transição entre o domínio estrutural latossólico e o lixiviado/ pedregoso constatou-se a presença de uma matriz, que compõe a fase fina, e nódulos. O fundo matricial na fase fina é amarelo-brunado, de estrutura de base aglomeroplásmica e, principalmente, granular; apresenta esqueleto quartzoso (45\% da área) e predomina sobre o plasma. Esse plasma apresenta cor bruno-amarelada (LN) e é opaco (LP), devido à matéria orgânica. A quantidade de poros aumenta em relação às amostras do conjunto inferior, enquanto o plasma diminui. Os nódulos ocupam mais da metade da lâmina e assemelham-se aos do latossolo; predominam aqueles arredondados de cor vermelha muito escura com muito esqueleto quartzoso ( $25 \%)$; o limite dos nódulos com o fundo matricial adjacente é abrupto.

Da base do domínio estrutural latossólico para o topo verifica-se a diminuição gradual da fração fina, até o seu desaparecimento na superfície; o aumento da porosidade e, sobretudo, o aumento da fração grosseira. As características de textura, estrutura, porosidade e quantidade de esqueleto mudam completamente do domínio argiloso/hidromórfico para este.

Diante dessa diferenciação pode-se inferir que o domínio estrutural lixiviado/pedregoso é discordante com o horizonte argiloso, entretanto, a morfologia mamelonar do contato é indicativa de processo de dissolução do topo do domínio estrutural argiloso/hidromórfico. Três hipóteses se colocam a partir disso: o material fino seria carregado pela água por erosão superficial ou perdido por eluviação para os horizontes subjacentes de jusante, ou, ainda, seria resultante da destruição das argilas. Todas essas formas, todavia, levariam a uma acumulação relativa do material grosseiro.

Nenhuma das hipóteses contradiz a outra. No entanto, a segunda hipótese parece ser menos provável, pois que nenhuma feição de depósito de iluviação foi observada nos domínios estruturais subjacentes. A primeira e terceira hipóteses não podem ser desconsideradas, pois apesar de não se ter observado nos solos crostas de superfície que demonstrem a erosão superficial, não se pode descartá-la, uma vez que poças nas estradas, adjacentes à toposseqüência, apresentavam água barrenta, sinal de material em suspensão. A terceira hipótese é mais difícil de ser comprovada no nível macroscópico e microscópio óptico.

O fato de haver blocos de couraça muito evoluída dentro do domínio estrutural pedregoso permite afirmar a existência de uma fácies protopsolítica. Não há nenhum traço de ferruginização que mostre que os nódulos vermelhos muito escuros, individualizados dentro da matriz do solo, possam ter se originado a partir desta matriz. O fato mais provável é que eles vêm da destruição dos blocos. Portanto, os blocos seriam reliquiais e assentavam-se sobre a couraça. Apesar da fácies protopsolítica ser mais quartzosa não invalida o fato de um desenvolvimento vertical a partir da rocha, pois, foi visto que no horizonte de alteração com plaquetas havia nódulos muito quartzosos, relacionados com as bandas do filito, cortadas por veios de quartzo. No nível microscópico o esqueleto, a porosidade e os nódulos predominam sobre o plasma da fase fina.

Essa relação entre esqueleto, porosidade e os nódulos com o plasma da fase fina, apenas reafirma a primeira e terceira hipótese levantadas a partir da análise macroscópica: que o material fino do domínio estrutural pedregoso foi 1) carreado por erosão superficial e/ou 2) perdido por erosão química dos elementos em solução, vindos da dissolução das argilas. Portanto, a micromorfologia não permitiu o avanço de interpretações conclusivas, mas levou à seleção das hipóteses para as análises subsequentes.

\section{Variação Textural Lateral e Vertical no Domínio Estrutural Lixiviado Pedregoso e Evidências Morfológicas da Dissolução das Argilas}

$\mathrm{Na}$ superfície da toposseqüência a fração grosseira forma uma camada contínua que diminui de espessura, de forma gradual, até desaparecer, aproximadamente na altura da tradagem TR5. Na montante e na jusante ela se compõe fundamentalmente de nódulos e pequenos blocos ferruginosos.

As figuras $5 \mathrm{~A}$ e $5 \mathrm{C}$ mostram a distribuição vertical e lateral das frações texturais. A fração grosseira alcança seu máximo na altura da trincheira C22. A partir desse ponto, em direção de C213 (montante) e de C27 (jusante) observa-se uma diminuição da quantidade dos fragmentos de quartzo e um aumento da fração fina e da quantidade de nódulos e blocos ferruginosos. O fato da textura passar de areno-argilosa na base do domínio estrutural, para arenosa na superfície, indica que há uma diminuição da fração fina nessa direção e confirma a acumulação relativa da fração grosseira.

Embora nos níveis macro e microscópico óptico não fosse comprovada a dissolução das argilas, as caulinitas observadas ao MEV mostraram uma morfologia externa irregular que, ao MET, em aumento de $100.000 \mathrm{X}$ representam figuras de dissolução (Fig. 5B).

A partir da trincheira $\mathrm{C} 22$, tanto em direção montante como jusante, a quantidade de nódulos ferruginosos, assim como a fração fina aumentam gradualmente.

Por outro lado, os nódulos e blocos 
ferruginosos desse domínio são semelhantes aos da fácies maciça e protopsolítica da couraça, largamente observados no domínio estrutural latossólico e no domínio estrutural argiloso/hidromórfico. Isto demonstra que o domínio estrutural lixiviado/ pedregoso é contínuo e que na parte média da toposseqüência é mais evoluído, consequentemente, a expansão do domínio estrutural lixiviado/pedregoso se produz de forma centrífuga e a partir do topo para a base da cobertura pedológica. De forma também centrífuga ele avança sobre o domínio estrutural latossólico e do topo para a base sobre o argiloso/hidromórfico. Essa transformação é devida, sobretudo, a uma erosão química das argilas uma vez que os domínios estruturais lixiviados/pedregosos estão sob floresta densa e sujeitos a provável erosão mecânica.

\section{Relação entre a Couraça de Montante e a de Jusante}

$\mathrm{O}$ resultado das análises químicas mostra (Fig. 5D) que $\mathrm{SiO}_{2}, \mathrm{FeO}_{3}$ e $\mathrm{Al}_{2} \mathrm{O}_{3}$ perfazem quase a totalidade da composição química de todos os perfis de solo da toposseqüência e que os outros elementos ( $\mathrm{TiO}, \mathrm{MnO}, \mathrm{MgO}, \mathrm{NaO}, \mathrm{KO}, \mathrm{PO}$ e $\mathrm{CaO}$ ) apresentam valores baixos, portanto não significativos. Quanto à distribuição dos elementos químicos nos domínios estruturais da toposseqüência, pode-se observar cinco agrupamentos de características semelhantes. Os grupos 1, 2 e 5 apresentam-se de forma descontínua ao longo da vertente e estão situados em superfície. Ao contrário, os grupos 3 e 4

Aparecem de forma contínua e situam-se mais no rumo à base da toposseqüência.

Destaque-se que: o grupo 1 corresponde à parte do domínio estrutural lixiviado/pedregoso que apresenta mais nódulos e blocos de couraça em superfície, daí o alto teor de ferro; os grupos 2 e 3 correspondem, ainda, ao domínio estrutural lixiviado/ pedregoso, mas com menos ferro e mais sílica que o anterior, relacionado com uma maior quantidade de fragmentos de quartzo; o grupo 5 é aquele que apresenta menor quantidade de ferro e está relacionado com o domínio estrutural latossólico de jusante. O domínio estrutural da couraça está englobado nos grupos 4 e 5, evidenciando homogeneidade na composição química.

Os estudos morfológico e químico dos solos permitiram introduzir argumentos importantes que levam a concluir pela continuidade da couraça na toposseqüência e reafirmam que os domínios estruturais se formaram a partir de um mesmo material de origem e, finalmente que a diferença de concentrações dos elementos químicos, da mineralogia e da textura, advêm da transformação e/ou diferenciação sucessiva de um domínio em outro.

\section{Evolução Pedomorfológica}

Pelo exposto pode-se iniciar a interpretação sobre a evolução pedomorfológica da área pela relação entre os níveis topográficos e as coberturas pedológicas e prosseguir com as evidências relativas à formação dos domínios geoquímicos relacionados.

Partindo-se de um raciocínio estrutural, o nível topográfico I, em ilhas dentro do nível II, pela sua forma irregular e distribui,ão descontínua sugere sua maior e pretérita continuidade na área. O Nível II é fortemente interpenetrado pelo III que apresenta tanto platôs como lombadas; isto evidencia: 1) que apesar da dissecação que marca o limite dos níveis, os platôs dos níveis I e II tinham continuidade com os do III e 2) que as vertentes rampeadas do nível II anunciam a convexização que é encontrada nas lombadas do nível III. Isto indica que as lombadas são posteriores aos platôs.

Analisando-se o mapa pedomorfológico identifica-se seis unidades pedomorfológicas (Fig. 2).

Nas altitudes entre 180 e $280 \mathrm{~m}$, localizadas em áreas pequenas e esparsas das partes oeste e nordeste da região correspondente aos platôs pouco dissecados, predomina a unidade de coberturas encouraçadas lateríticas ferruginosas onde as declividades não ultrapassam $2 \%$. Originadas dos filitos, ardósias, xistos e às vezes do calcário intercalado aos metapelitos, tais coberturas apresentam forte diferenciação pedológica vertical e diferenciação lateral incipiente (Fig.2).

Entre os 145 e os $280 \mathrm{~m}$ de altitude, em duas largas faixas no sentido norte-sul, uma na parte centrooeste e outra no extremo leste, ocorre a unidade das coberturas lateríticas pouco transformadas, onde a couraça ferruginosa laterítica transforma-se em latossolo (Fig.2 B1, B2, B3 e B4) caracterizando um sistema de transformação. O relevo dessa unidade apresenta, além de inselbergues, platôs com dissecação fraca e declividades que variam de 10 a 25 $\%$ nas vertentes retilíneas. As rochas subjacentes são o filito, a ardósia, o xisto e, às vezes, o calcário intercalado nos metapelitos. A diferenciação vertical da cobertura pedológica é forte e a diferenciação lateral é fraca.

Ocupando grandes áreas da parte central do mapa, em uma longa faixa norte-sul, e partes mais restritas do setor leste, desenvolve-se a unidade de coberturas lateríticas medianamente transformadas (Fig.2 C1 e C2) originadas dos filitos, ardósias e xistos, que apresenta um sistema de solos do tipo latossolo/argissolo, com diferenciação lateral e vertical forte. Seu relevo constitui-se em platôs com dissecação entre 0 e $2 \mathrm{~km} / \mathrm{km}^{2}$ e declividade entre 0 e 2 $\%$. Suas vertentes são rampeadas com perfil irregular, declividade entre 2 a $4 \%$, e altitudes entre 170 e 250 $\mathrm{m}$; e convexo-retilíneo-côncavas, com grau de dissecação próximo ao dos platôs, declividade entre 2 a $6 \%$ e altitudes entre 170 a $210 \mathrm{~m}$.

Ocupando os setores nordeste e noroeste da região e manchas isoladas no setor sudoeste encontrase a unidade de cobertura de argissolo cuja diferenciação vertical é forte e a lateral é fraca (Fig.2D). A cobertura associa-se à alteração de filitos, ardósias e xistos e à transformação da couraça. Desenvolve-se entre 171 e $22 \mathrm{~m}$ de altitude, sobre lombadas, cujas encostas convexas apresentam dissecação entre 0 e $2 \mathrm{~km} / \mathrm{km}$, declividades de 2 a $6 \%$. Entre 195 a $241 \mathrm{~m}$, sobre colinas cujas vertentes 


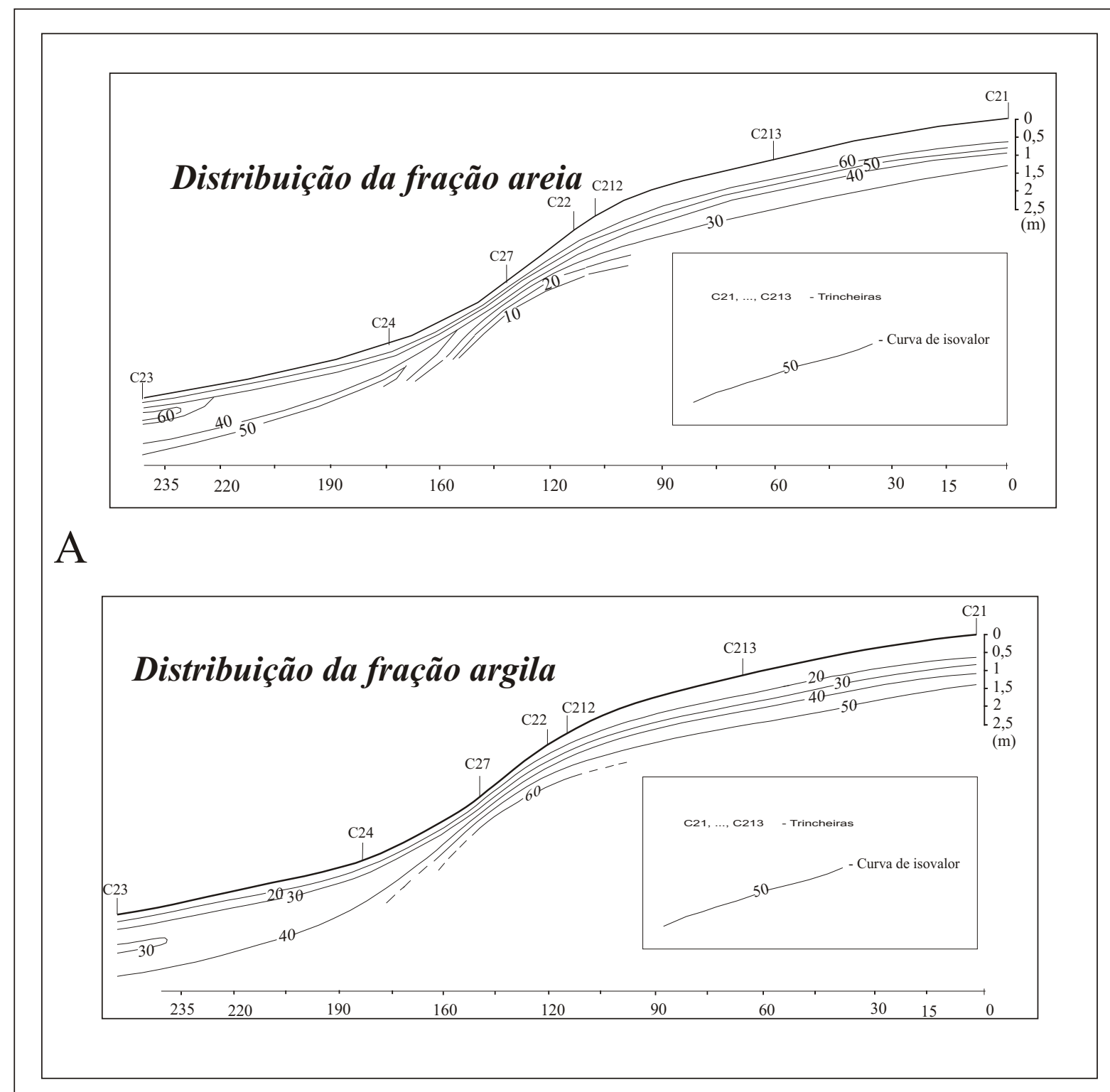

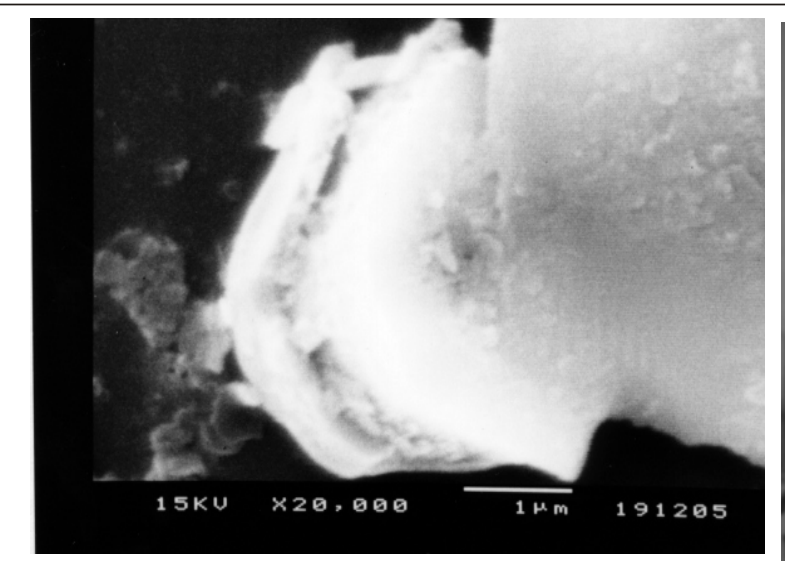

Micrografia ao MEV: caolinita que apresenta um abaulamento no centro do cristal

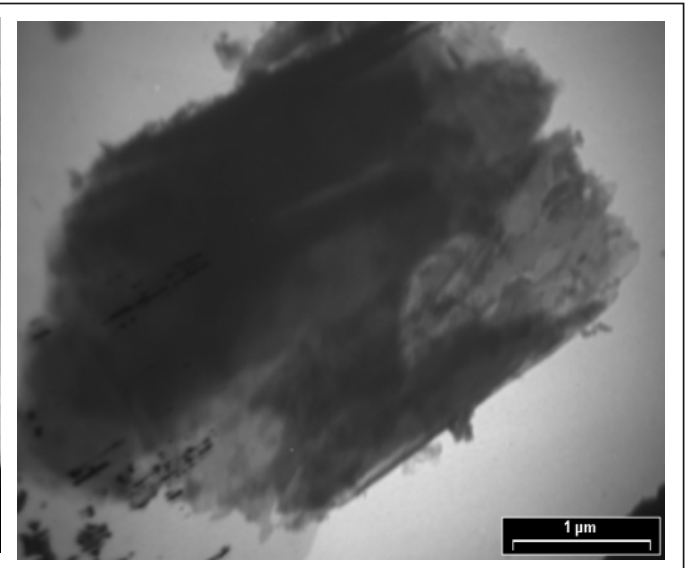

Micrografia ao MET: caolinita que apresenta figura de dissolução nas bordas e no centro do cristal

Figura 5 A-B. Frações texturais, dissolução de argila e elementos químicos 


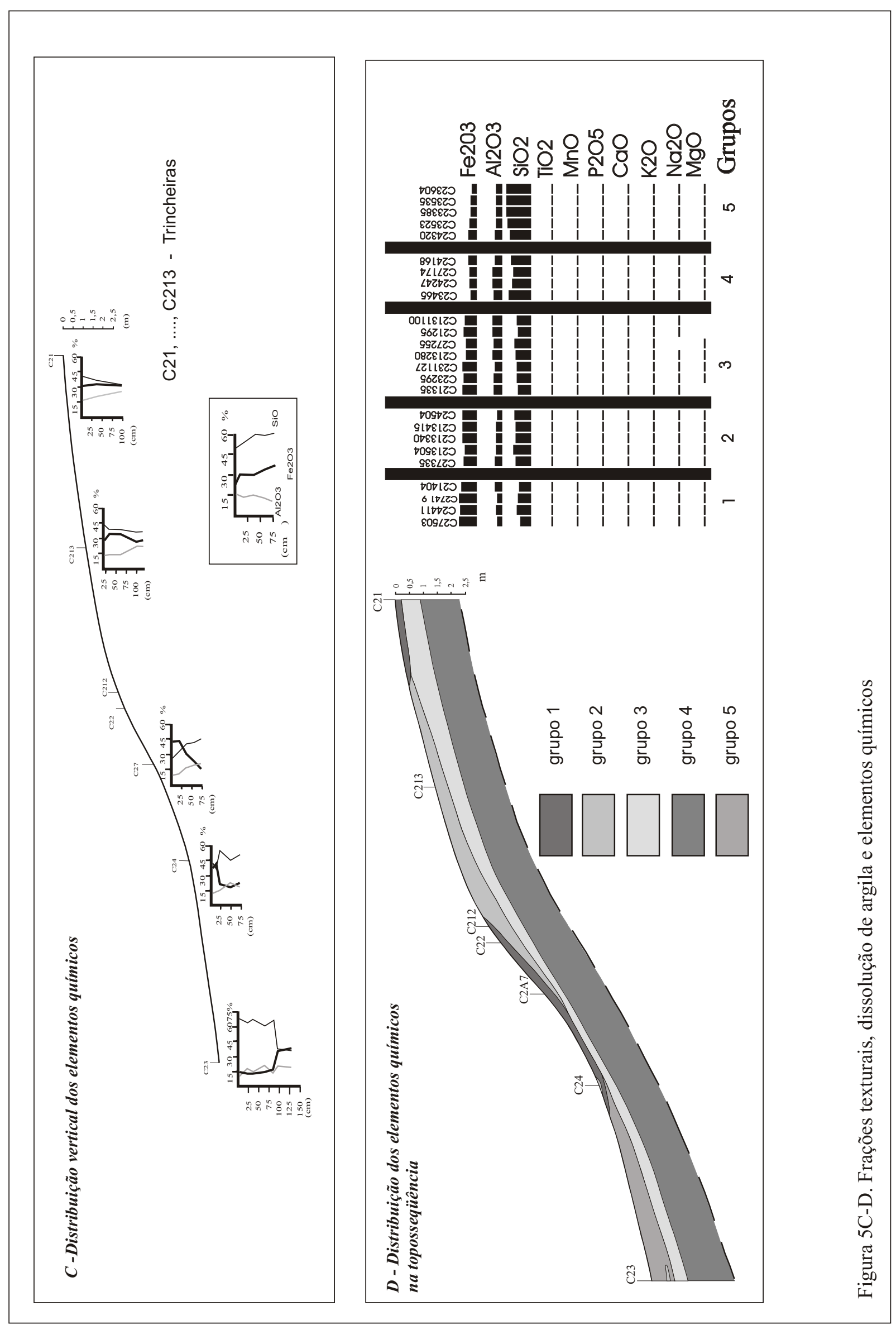


convexas apresentam dissecação entre 0,9 e 2,5 $\mathrm{km} / \mathrm{km}$ e declividade que varia de 3 a $15 \%$.

Correspondendo às lajes de rochas (aproximadamente $150 \mathrm{~m}$ de altitude), às serras e inselbergues (altitudes superiores a $230 \mathrm{~m}$ ), e aos depósitos de vertente, encontra-se a unidade das coberturas litodependentes, dos depósitos detríticos e dos afloramentos de rocha. Originadas de quartzitos e xisto-filitos intercalados por lentes de rochas ultrabásicas, estão de forma destacada ao longo do limite sudoeste da região bem como em ilhas, esparsas, organizadas em duas faixas no sentido nortesul, uma no setor centro-oeste, e outra no extremo leste. Suas diferenciações, tanto lateral quanto vertical, são fracas.

A formação dos domínios geoquímicos de alteração e de pedogênese constatados e apresentados na Fig.6 na toposseqüência $\mathrm{C} 2$ permitiram discutir o exposto a seguir.

Os solos lateríticos com couraça ferruginosa são próprios das regiões tropicais úmidas com forte contraste entre as estações (1450 mm de chuva; $28 \mathrm{C}$; $70 \%$ de umidade relativa do ar e 6 meses secos) (Tardy, 1993). Nessas condições climáticas as couraças ferruginosas lateríticas destroem-se pelo topo e reconstroem-se pela base, mantendo sua permanência.

Os dados morfológicos apresentados neste trabalho ofereceram informações importantes no sentido de demonstrar: que na área estudada desenvolveu-se um sistema de transformação de couraça ferruginosa laterítica em latossolo, como aquele encontrado por Nahon, Melfi e Conte (1989) a qual subsiste nos platôs (toposseqüência A) e reflete as condições de sua formação (clima e mecanismos geoquímicos). $\mathrm{Na}$ toposseqüência $\mathrm{C} 2$, no domínio estrutural da couraça, a mineralogia das fases ferruginosas é sempre hematita, goethita e caolinita o que pode estar ligado a uma degradação normal, resultante da hidratação da hematita e da transformação da goetita e formação de caulinita (Fig. 4), tal como demonstrado por Nahon (1976) e Nahon e Millot(1977), na África.

Estudos realizados na África e no Brasil mostraram que perfis lateríticos encouraçados pelo ferro são desmantelados à medida que o clima se torna cada vez mais seco (Chauvel, 1976; Leprun, 1979; Boulet, 1978; Millot, 1980; Nascimento, 1993) ou cada vez mais úmido (Nahon, Melfi e Conte, 1989; Beauvais e Tardy, 1991).

Esta segunda via é a que se desenvolve em Conceição do Araguaia, onde o desmantelamento da couraça se dá sob floresta e sob uma pluviosidade de $1650 \mathrm{~mm}$ anuais. Segundo Beauvais e Tardy (1991) o desmantelamento se processa pelo efeito conjugado da umidade e da decomposição da matéria orgânica e da respiração das raízes, que levam à hidratação e redução, responsáveis pela transformação da hematita em goethita, e da caolinita em gibbsita, e pela dissolução seletiva do ferro em relação ao alumínio. A seqüência mineralógica que vai da couraça ferruginosa - hematita, goethita, caolinita - à fase fina do domínio estrutural latossólico ao lixiviado/ pedregoso - goetita, caolinita, gibbsita corrobora esse modelo de transformação. A figura 4 ressalta, ainda, as diferentes fases dessa transformação.

O produto do desmantelamento da couraça é formação de coberturas de solos vermelhos, microagregados (Beauvais e Tardy, 1991), como aqueles presentes nas toposseqüências B1, B2 e C1 (Fig. 2).

Duas grandes famílias de processos estão envolvidas na geração dos solos: os de formação de solo e os de transformação dos solos que podem ser interpretados a partir das feições pedológicas (Faning e Faning, 1989). Essas duas famílias de processos formam, respectivamente, os compartimentos bem e mal drenados da paisagem.

Em relevos de colinas passa-se dos topos bem drenados (domínio laterítico sensu strictu) aos vales pobremente drenados (domínio hidromórfico), em sistemas de solos lateríticos vermelhos - solos amarelados e cinza hidromórficos (Peterschimitt, Fritsch, Rajot e Herbillon, 1994), enquanto em relevos de platôs essa seqüência ocorre, às vezes, da borda para o centro do platô e freqüentemente nas vertentes dos platôs (Chauvel, 1976, Coventry, Taylor e Fitzpatrick, 1983) como é o caso da toposseqüência C2.

A couraça ferruginosa laterítica constituiuse no material de origem dos solos latossólicos em Conceição do Araguaia (Fig. 6A). Esses solos juntamente com a couraça ferruginosa ocupam as posições melhor drenadas da paisagem (Fig. 2, 6A e 6B). As feições pedológicas, agrupadas no domínio estrutural latossólico associadas aos domínios mineralógicos podem ser entendidas como o resultado dos processos de hidratação e redução dos óxidos de ferro, dissolução da caolinita e formação de gibbsita nos horizontes do latossolo (Fig. 6A e 5B).

$\mathrm{O}$ domínio estrutural argiloso /hidromórfico é indicativo de que transformação inicia-se na parte média da vertente e revela a ocorrência de processos diferentes daqueles operantes nos platôs e na montante das encostas. De fato, a cor das matrizes (5 a 10YR) e cutãs de estresse são comuns nesse domínio estrutural e no de alteração da rocha (Fig. 6A) tal como descritas por Chauvel (1976) como resultado da saturação periódica ou flutuação de lençol freático.

A mudança de cor e as relações geométricas entre os domínios estruturais latossólico e o argiloso/hidromórfico podem estar indicando que o amarelecimento resulta de transformação por dissolução seletiva dos óxidos de ferro (hematita e goethita) em relação ao $\mathrm{Al}$, como a descrita por Peterschimitt, Fritsch, Rajot e Herbillon (1994).

A contraposição entre os compartimentos bem drenados e os periodicamente saturados, bem como a irreversibilidade das transformações originadas a partir dos sistemas de lençol, mostram que a única evolução possível nas condições atuais é a expansão das formações hidromórficas e da rede hidrográfica, que estão acopladas à regressão das formações lateríticas, bem drenadas, para as posições mais altas das vertentes (Peterschimitt, Fritsch, Rajot e Herbillon, 1994). Esse modelo pode explicar a generalização da hidromorfia nos solos da unidade de cobertura de argissolo (Fig. 2 e 6B). 

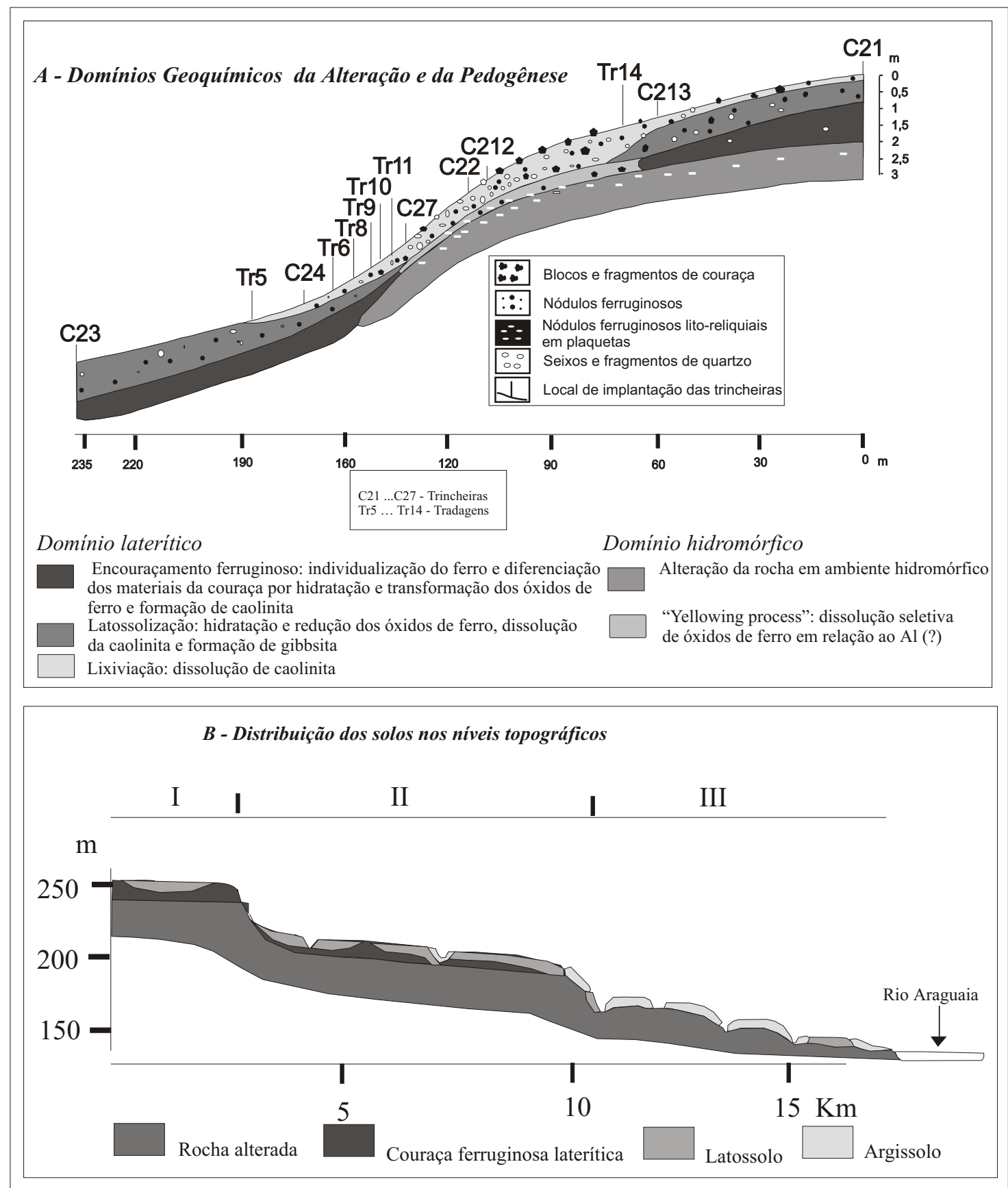

Figura 6. Domínios geoquímicos da alteração e da pedogênese e distribuição dos solos nos níveis topográficos

Nesse estágio uma mudança importante da morfologia da vertente é acompanhada pela instalação da drenagem que religa-se aos sistemas de lençol, promovendo a progressão do Argissolo na direção de montante das toposseqüências. As formas planas que caracterizam os platôs vão, assim, dando lugar às formas de encostas convexo-retilíneo-côncavas até às formas de lombadas convexas.

A partir dos dados disponíveis não se sabe que tipo de evento levou à instalação dessa drenagem. Sabe-se, no entanto, que a sua instalação é posterior ao evento de encouraçamento, uma vez que algumas das drenagens correm diretamente sobre a couraça, tanto nos níveis 1 e 2 como no nível 3 nos planos rampeados.
Como essas drenagens são contínuas e partem dos platôs mais altos e seguem em direção dos rios Araguaia, Arraias e Páu-D'Arco, significa que a superfície é a mesma e era, anteriormente, contínua.

As unidades pedomorfológicas atuais se organizam, assim, a partir do centro da área em direção das drenagens de maior ordem. O elo de ligação entre os compartimentos de relevo encontra-se, pois, nas coberturas pedológicas e à medida que a couraça ferruginosa se transforma o mesmo ocorre, sucessiva e gradualmente com a morfologia dos relevos.

\section{Conclusões}

A análise da topografia e da pedomorfologia 
revelou que não há uma relação estreita entre os níveis topográficos e a forma do relevo, mas por outro lado, os sistemas de solos apresentam correspondência com o relevo. Desta maneira pode-se sugerir que: 1) à medida que os sistemas de solos evoluem, a forma do relevo se modifica e 2) paralelamente a isto a drenagem se instala e se adensa.

A distribuição espacial e a evolução das unidades pedomorfológicas acompanham, assim, a evolução dos sistemas de solos onde os mecanismos de erosão mecânica superficial parecem exercer uma influência restrita e localizada.

A evolução geoquímica dos horizontes dos solos revelou a presença atual de sistema de transformação pedológica vertical e lateral da couraça ferruginosa.

A cobertura superficial inconsolidada a que se referia Boaventura (1974) é, na verdade, constituída por materiais de alteração e de solos desenvolvidos da rocha subjacente, portanto "in situ", o que contraria a idéia da grande pediplanação pleistocênica. Entretanto, revelou a existência de uma grande superfície derivada de um longo processo de laterização que conduziu à formação de couraça ferruginosa, antes contínua, cujos mecanismos de alteração e de pedogênese foram os responsáveis pelo seu desequilíbrio pedo-bioclimático que conduziu ao aplainamento e abaixamento do relevo atual.

A couraça ferruginosa laterítica na área estudada está fora do domínio climático para a sua formação, o que indica que ela é reliquial e testemunha fase climática anterior.

A distribuição e a maneira como o latossolo transformou a couraça conduziu a uma leve convexização das encostas dos platôs e abaixamento dos relevos. Por outro lado, o aparecimento e a expansão recente e progressiva do argissolo faz desaparecer as formações bem drenadas, além de promover uma mudança fundamental na forma do relevo, levando ao aparecimento de uma nova compartimentação da paisagem, tal como esta se encontra hoje.

\section{Agradecimento}

Ao prof. Dr. Antônio Carlos DeBiase pela leitura do manuscrito e pela versão inglesa do abstract.

\section{Referências Bibliográficas}

Beauvais, A. e Tardy, Y. (1991) Formation et dégradation des cuirasses ferrugineuses sous climat tropical humide, à la lisière de la forêt équatoriale. C. R. Acad. Paris, Géochimie/Geochemistry, t 313. Série II: 1539-1545.

Bocquier, G. Rognon, P. ; Paquet, H. e Millot, G. (1977) Géochimie de la surface et formes du relief. II. Interprétation pédologique des dépressions annulaires entourant les inselbergs. Sci. Géol. Bull., Strasbourg, 30 (4): 245-253.

Boulet, R, Lucas, Y, Fritsch, E. e Paquet, H. (1993) Géochimie des paysages: le rôle des couvertures pédologiques. In: H. Paquet e N. Clauer (editores) Coll. "Sédimentologie et Géochimie de la Surface à la mémoire de Georges Millot'. Le Colloques de l'Académie des Sciences et du Cadas, Paris: 55-76.

Boulet, R. (1978) Existence des systèmes a forte différenciation latérale en millieu férrallitique guyanais: un nouvel exemple de couvertures pédologiques en déséquilibre. Sciences du Sol, (2):75-82.

Boulet, R., Bocquier, G., Millot, G. (1977) Géochimie de la surface et formes du relief. I. Déséquilibre pédobioclimatique dans les couvertures pédologiques de l'Afrique Tropicale de l'Ouest et son rôle dans l'aplanissement des reliefs. Sci. Géol. Bull., Strasbourg, 30 (4): 235-243.

Boulet, R.; Chauvel, A.; Humbel, F.X. e Lucas, Y. (1982) Analyse structurale et cartographie en pédologie. I- Prise en compte de l'organisation bidimensionelle de la couverture pédologique: les études de toposéquences et leurs principaux apports à la connaissance des sols. Cah. ORSTOM, Sér. Pédol., Paris. XIX (4):309321.

Boulet, R.; Humbel, F.X. e Lucas, Y. (1982b) Analyse structurale et cartographie en pédologie. IIUne méthode d' analyse prennant en compte l'organisation tridimensionnelle des couvertures pédologiques. Cah. ORSTOM, Sér. Pédol., Paris. XIX(4):323-339.

Brewer, R. (1976) Fabric and Mineral Analysis of soil. 2d. ed. New York: Robert E. Krieger Publ. Co., $482 \mathrm{p}$.

Busche, D. e Erbes, W. (1987) Silicate karst landform of southern Sahara (north-eastern Niger and southern Libya). Z. Geomorph., N. P. Suppl. $\mathrm{Bd},(64): 55-72$.

Camargo, O. A.; Moniz, A.C.; Jorge, J. A. e Valadares, J. M. A. S. (1986) Métodos de análise química, mineralógica e física de solos do Instituto Agronômico de Campinas. Campinas, Bol. Tecn. no. 106:94.

Castro, S. S., (1989) Sistemas de transformação pedológica em Marília, SP. : B latossólicos e B texturais. São Paulo. Tese de Doutoramento, USP-FFLCH, Departamento de Geografia. $274 \mathrm{p}$.

Chauvel, A. (1976) Recherches sur la transformation des sols ferralitiques dans la zone tropicale à saisons contrastées. Thése Mém. ORSTOM et Sci. Strasbourg, (62) $532 \mathrm{p}$.

Coventry, R. J.; Taylor, R.M. e Fitzpatrick, R. W. (1983) Pedological significance of the gravels in some red and grey earths of Central North Queensland. Aust. J. Soil Res., 21:219-240.

De Biasi, M. (1970) Cartas de Declividade: Confecção e Utilização. Geomorfologia, São Paulo. (21):8-12.

Faning e Faning, G. (1989) Soil morfology, genesis and classification. John Wiley \& Sons. 395 p.

Filizola, H. F., (1993) O papel da erosão geoquímica 
na evolução do modelado da Bacia de Taubaté SP. Tese de Doutoramento. São Paulo, USPFFLCH, Departamento de Geografia. 114 p.

Fritsch, E. (1984) Les transformations d'une couverture ferrallitique: analyse minéralogique et structurale d'une toposséquence sur schistes en Guyane Française. Thèse 3 cycle. Univ. Paris VII, 190 p.

Fritsch, E., Valentin, C., Morel, B., Leblond, P. (1990) La couverture pédologique : interactions avec les roches, le modelé et les formes de dégradation superficielle. In ORSTOM, Structure et fonctionnement hydropédologique d'un petit bassin versant de savane humide. Études et Thèses, Ed. ORSTOM.:31-57.

Fritsch, E.; Fitzpatrick, R. W.; Melfi, A. J.; Herbillon, A. J. e Boulet, R. (1999) Soil features at topossequence scale for identifying structures, waterflows and processes either past or present. Geoderma (no prelo)

Fritsch, E.; Peterschimitt, E. e Herbillon, A. J. (1992) A structural approach to the regolit: identification of structures, analysis of structural relationships and interpretations. Sci. Géol. Bul. 45(2):77-97.

Leprun, J.C. (1979) Les cuirasses ferrugineuses des pays cristallins de l'Afrique Occidentale sèche. Genèse, Transformations, dégradation. Sci.Géol. Mém., Strasbourg, 58:224.

Löffler, E. (1978) Karst features in igneous rocks in Papua New Guinea. In J.L. Davis e M. A. J. Williams (editores) Landform Evolution in Australasia.: 238-249.

Lucas, Y. 1989. Systèmes pédologiques en Amazonie brésilienne. Equilibres, déséquilibres et transformations. Thèse Doc., Univ. Poitiers. $157 \mathrm{p}$.

Lucas, Y.; Chauvel, A.; Boulet , R.; Ranzani, G.J.; Scatolini, F. (1984) Transição latossolos podzóis sobre a Formação Barreiras na região de Manaus, Amazônia. Revista Brasileira de Ciência do Solo (8): 325 - 335.

McFarlane, M. J. (1976) Laterite and landscape. Academic Presss. London.

McFarlane, M. J. e Twidale, C. R. (1987) Karstic features associated with tropical weathering profiles. Z. Geomorph. N. F. Suppl.-Bd (64): 73-95.

Millot, G. (1977) Géochimie de la surface et formes du relief. Présentation. Sci. Géol., Bul., 30(4):229-233.

Millot, G. (1980) Les grands aplanissements des socles continentaux dans les pays subtropicaux, tropicaux et désertiques. Mém. Hors sér. Soc. Géol., France, 10:295-305.

Müller, J.P. e Bocquier, G. (1986) Dissolution of kaolinites and accumulation of iron oxides in lateritic-ferruginous nodules: mineralogical and microstructural transformations. Geoderma, (37):113-136.
Nahon, D. (976) Cuirasses férrugineuses et encroûtements calcaires au Sénégal occidental et en Mauritanie. Systèmes atlantiques évolutifs: géochimie, structures, relais et coéxistence. Thèse Doc. és Sci, Mémoire no. 44, Univ. L. Pasteur de Strasbourg, Institut de Gélogie. 232p.

Nahon, D. e Millot, G. (1977) Géochimie de la surface et formes du relief. V. Enfoncement géochimique des cuirrases ferrugineuses par épigénie du manteau d'altération des roches mères gréseuses. Influences sur le paysage. Sc. Géol. Bull., Strasbourg, 30(4) :275-282.

Nahon, D.; Melfi, A.J. e Conte, N.C. (1989) Présence d'un vieux système de cuirasses ferrugineuses latéritiques en Amazonie du Sud. Sa transformation in situ en latosols sous la forêt équatorial actuelle. C. R. Acad. Sci. Paris, Sér. II., t 308:755-760.

Nascimento, N. R. e Carvalho, M. L. M. (1996) Evolução das coberturas pedológicas da Bacia do Rio Corumbataí - SP. XXXIX Congresso Brassileiro de Geologia. Geologia e Sociedade. SBG. 01 a 06 de setembro. Salvador. (6):29652972.

Nascimento, N.R. (1993) Sistemas de transformação pedológica "solos lateríticos com couraça ferruginosa em silcrete e/ou planossolo": Aplicação à pedomorfologia do médio vale do rio Paramirim- BA. São Paulo. Tese de Doutoramento. Instituto de Geociências- USP. $237 \mathrm{p}$.

Pérez, D. H.; Nascimento, N. R. do e Nicola, S. M. (1998) Formación de conjuntos pedregosos cuarzosos a partir de la transformación de suelos lateríticos com coraza ferruginosa, en el sur de la "Amazonia Brasileira". 16 th. World Congress of Soil Science. 20-26 de agosto de 1998, Montpellier, França. CD ROM..

Peterschimitt, E.; Fritsch, E.; Rajot, J.L. e Herbillon, A. J. (1996) Yellowing, bleaching and ferritisation processes in soil mantle of the Western Ghâts, South India. Geoderma, (74):235-253

Sanches, M. C. (1993) A Propósito das Cartas de Declividade. In: Simpósio de Geografia Física Aplicada, 5, 1993. São Paulo. Anais. São Paulo, FFLCH.

Silva, G. G. da; Lima, M. I. C. de; Andrade, A.R. F. de; Issler, R. S. e Guimarães G. (1974) Geologia das Folhas SB.22 Araguaia e parte da Folha SC.22 Tocantins.. In Projeto RADAMBRASIL Levantamento de recursos naturais - Departamento Nacional da Produção Mineral. Projeto RADAM. Rio de janeiro, 4: 2143.

Tardy, Y.; Melfi, A. J. e Valeton, I. (1988) Climats et paléoclimats tropicaux périatlantiques. Rôle des facteurs climatiques et thermodynamiques: temperature et activité de l'eau, sur la répartition et la composition minéralogique dês bauxites et dês cuirasses ferrugineuses au Brésil et em Afrique. C. R. Acad. Pris, 
306(2):289-295.

Tardy, Y.; Bardossy, G. e Nahon, D. (1988) Fluctuations de l'activité de l'eau et succession de minéraux hydratés et deshidratés au sein des profils latéritiques ferrugineux et bauxitiques. C. R. Acad. Sci. Paris, 307,(2):753-759.

Tardy, Y. (1993) Pétrologie des Latérites et des Sols Tropicaux. Masson. Paris. $459 \mathrm{p}$.

Thomas, M. F. (1994) Geomorphology in the Tropics. John Wiley \& Sons, Chichester, $460 \mathrm{p}$. 